\title{
Synthesis and biological evaluation of novel
} indole-2-one and 7-aza-2-oxindole derivatives as anti-inflammatory agents

This article was published in the following Dove Press journal:

Drug Design, Development and Therapy

13 October 2014

Number of times this article has been viewed

\author{
Gaozhi Chen ${ }^{1, *}$ \\ Lili Jiang ${ }^{2, *}$ \\ Lili Dong ${ }^{2}$ \\ Zhe Wang' \\ Fengli $\mathrm{Xu}^{2}$ \\ Ting Ding ${ }^{3}$ \\ Lili Fu' \\ Qilu Fang' \\ Zhiguo Liu ${ }^{1,4}$ \\ Xiaoou Shan ${ }^{2}$ \\ Guang Liang' \\ 'Chemical Biology Research Center, \\ School of Pharmaceutical Sciences, \\ ${ }^{2}$ Department of Pediatrics, The 2nd \\ Affiliated Hospital, ${ }^{3}$ Department of \\ Pharmacy, The 5th Affiliated Hospital, \\ Wenzhou Medical University, Lishui, \\ Zhejiang, People's Republic of China; \\ ${ }^{4}$ Wenzhou Undersun Biotchnology \\ Co, Ltd, Wenzhou, Zhejiang, People's \\ Republic of China \\ *These authors contribute equally to \\ this work
}

Correspondence: Guang Liang Chemical Biology Research Center, School of Pharmaceutical Sciences,

Wenzhou Medical University,

Wenzhou, Zhejiang 325000,

People's Republic of China

Tel +86 57786699396

Fax +86 57786699396

Email wzmcliangguang@।63.com

Xiaoou Shan

Department of Pediatrics,

The 2nd Affiliated Hospital,

Wenzhou Medical University,

Wenzhou, Zhejiang 325000,

People's Republic of China

Tel +86 I37 77779922

Email sssxooo@sina.com

\begin{abstract}
Sepsis, a typically acute inflammatory disease, is the biggest cause of death in ICU (intensive care unit). Novel anti-inflammatory alternatives are still in urgent need. In this study, we designed and synthesized 30 indole-2-one and 7-aza-2-oxindole derivatives based on the skeleton of tenidap, and their anti-inflammatory activity was determined by evaluating the inhibitory potency against lipopolysaccharide (LPS)-stimulated tumor necrosis factor (TNF)- $\alpha$ and interleukin (IL)-6 release in RAW264.7 macrophages. Quantitative SAR (structure-activity relationship) analysis revealed that a high molecular polarizability and low lipid/water partition coefficient $(\mathrm{ALogP})$ in indole-2-one are beneficial for anti-inflammatory activity. Moreover, compounds $7 \mathrm{i}$ and $8 \mathrm{e}$ inhibited the expression of TNF- $\alpha$, IL-6, COX-2, PGES, and iNOS in LPS-stimulated macrophages, and $7 \mathrm{i}$ exhibited a significant protection from LPS-induced septic death in mouse models. These data present a series of new indole-2-one compounds with potential therapeutic effects in acute inflammatory diseases.
\end{abstract}

Keywords: anti-inflammation, macrophages, sepsis

\section{Introduction}

Sepsis, caused by the immune system's response to a serious infection, most commonly bacteria, and characterized by organ dysfunction, has a high mortality of $20 \%-25 \%{ }^{1-3}$ Research efforts have defined sepsis as a syndrome of hyperinflammation. ${ }^{4,5}$ The secretion of inflammatory mediators accompanied by massive neutrophil infiltration is an important pathological factor and consequently causes autoinjury to the host, leading to multiple organ failure and death. ${ }^{6}$ Cytokines such as interleukin (IL)-12, IL-6, IL-1 $\beta$, and tumor necrosis factor (TNF)- $\alpha$ play significant roles in this inflammatory storm. ${ }^{7,8}$ They are also involved in the pathogenesis of other inflammation-mediated diseases, such as atherosclerosis, diabetic complications, cancer, rheumatoid arthritis, and inflammatory bowel disease, through a series of cytokine signaling pathways. ${ }^{9,10}$ Thus, inflammatory cytokines such as TNF- $\alpha$ and IL- 6 are important molecular targets in anti-inflammatory drug discovery, ${ }^{11}$ and pharmacological deregulation of cytokines by small-molecule inhibitors may contribute to the attenuation of sepsis.

Non-steroidal anti-inflammatory drugs (NSAIDs) play an important role in the therapy of inflammation or inflammation-related diseases. ${ }^{12}$ Bernard et a ${ }^{13}$ found substantial reductions in sepsis-induced prostacyclin and thromboxane excretion and mortality by treated septic patients with 48 hours of intravenous NSAIDs (ibuprofen). Similar clinical outcomes have been observed by Winning et al using NSAID treatments. ${ }^{14}$ In another large-scale clinical study with more than 9,000 patients in ICU (intensive care unit), Eisen et $\mathrm{al}^{15,16}$ observed a strong association between administration of NSAIDs 
to patients within 24 hours of the onset of SIRS (systemic inflammatory response syndrome) or sepsis and reduced mortality. However, the gastrointestinal side effects limit their therapeutic utility. ${ }^{17,18}$ Thus, the development of novel anti-inflammatory agents as alternatives to NSAIDs is an urgent need. ${ }^{19}$ A large number of small-molecule inhibitors of pro-inflammatory cytokine secretion have been widely investigated, some of which have advanced to clinical trials. ${ }^{20,21}$ In the past several years, our group has designed and synthesized a number of small molecules from the leading structures, including curcumin and chalcones, and evaluated their antiinflammatory effects in lipopolysaccharide (LPS)-stimulated macrophages and LPS-induced septic mouse models. ${ }^{22-24}$

Since being isolated for the first time in 1866, indole has been found to be one of the most important portions in natural occurring compounds. Moreover, indole has exhibited wide applications in medicinal chemistry and is the precursor of many pharmaceuticals such as indomethacin and tenidap ${ }^{25}$ (Figure 1). Compared with traditional NSAIDs like piroxicam and diclofenac, tenidap has been shown to be more effective in the clinical treatment of rheumatic arthritis as a cytokine modulator and COX/5-LOX inhibitor. ${ }^{26,27}$ However, the oxidative metabolites of the thiophene moiety bring about the liver and kidney toxicity of tenidap, which restricts its clinical application. ${ }^{28,29}$

Encouraged by these findings and with the incentive of developing alternative anti-inflammatory agents, we designed three series of indole-2-one derivatives with the following considerations: 1) the thiophene ring in the tenidap molecule was replaced with a phenyl or heterocyclic ring, 2) a 7-aza-2-oxindole skeleton was introduced into the tenidap structure, and 3 ) the linker between the phenyl and indole-2-one was modified by an amino group. All of these indole-2-one derivatives were synthesized, and then the anti-inflammatory activities both in vitro and in vivo were evaluated.

\section{Materials and methods \\ Chemical synthesis}

\section{General information}

Before use, solvents were distilled under positive pressure of dry argon by standard methods. Acetonitrile and tetrahydrofuran were distilled over calcium hydride and stored over $4 \AA$ molecular sieves. All starting materials and reagents were either commercially available or previously synthesized. Unless otherwise noted, chemicals were obtained from local suppliers and were used without further purification. All reactions were monitored by thin-layer chromatography $(250 \mu \mathrm{m}$ silica gel $60 \mathrm{~F}_{254}$ glass plates). Nuclear magnetic resonance (NMR) spectra were recorded on Bruker $600 \mathrm{MHz}$ instruments (Bruker Corporation, Billerica, MA, USA), and the chemical shifts were presented in terms of parts per million, with tetramethylsilane as the internal reference. Electronspray ionization mass spectra in positive mode (ESI-MS) data were obtained with a Bruker Esquire 3000+ spectrometer. Column chromatography purifications were carried out on Silica Gel 60 (E. Merck, 70-230 mesh [EMD Millipore, Billerica, MA, USA]).

\section{Synthesis of intermediates I and 2}

Allyl bromide (2.0 equiv) was added to a solution of hydroxybenzaldehyde (1.0 equiv) and $\mathrm{K}_{2} \mathrm{CO}_{3}$ (3.0 equiv) in acetonitrile and refluxed for 3-4 hours. The mixture was cooled to room temperature, and the solvent was then removed under vacuum. The residue was purified by chromatography over silica gel using petroleum ether/ethyl acetate as the eluent to give intermediates 1 and 2 .

\section{Synthesis of intermediates 3,4 , and 5}

A reaction mixture of the 4-fluorobenzaldehyde (1.0 equiv) and $\mathrm{N}$-methylpiperazine/morpholine/piperazine (3.0 equiv) in 2 -methoxyethanol was stirred at $110^{\circ} \mathrm{C}$ for

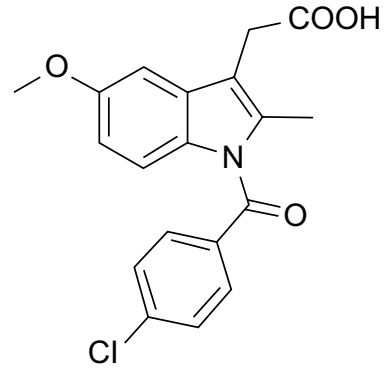

Indomethacin

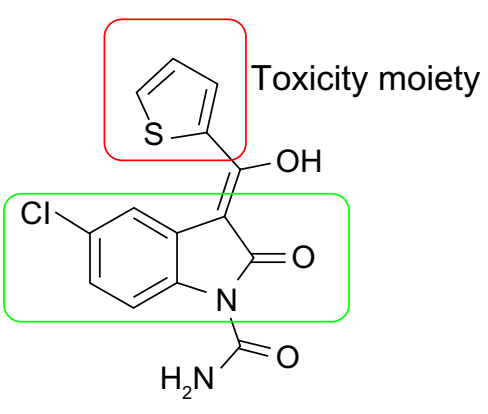

Tenidap

Figure I Chemical structures of indomethacin and tenidap. Indole-2-one skeleton (green rectangle) and the moiety (red rectangle) which may contribute to the toxicity are marked. 
3-5 hours. The solvent was then removed under vacuum. The residue was washed with brine and filtrated. The solid was purified by chromatography over silica gel using petroleum ether/methanol as the eluent to give intermediates 3,4 , and 5 .

\section{General procedure for synthesis of compounds $6 \mathrm{a}-6 \mathrm{~h}$ and $7 \mathrm{a}-7 \mathrm{~g}$}

To a stirred solution of indole-2-one or 7-azaoxindole (1.0 equiv) in absolute ethanol, the various aldehydes were added, including intermediates $1-5$ (1.0 equiv). After stirring at room temperature for 5 minutes, $\mathrm{NaOEt} / \mathrm{EtOH}(0.5 \mathrm{~mL})$ was added, and then the mixture was stirred at room temperature overnight. The solvent was then removed under vacuum. The residue was washed with brine and then extracted with ethyl acetate. The organic layer was dried over anhydrous magnesium sulfate and concentrated under vacuum. The solid was purified by chromatography over silica gel using ethyl acetate/petroleum ether as the eluent to afford desired compounds $6 \mathrm{a}-6 \mathrm{~h}$ and $7 \mathrm{a}-7 \mathrm{~g}$.

\section{Synthesis of compounds $6 \mathrm{i}$ and $7 \mathrm{~h}$}

A reaction mixture of the compound $6 \mathrm{f}$ or $7 \mathrm{e}$ in ethyl formate was stirred overnight at $50^{\circ} \mathrm{C}$. The solvent was then removed under vacuum. The residue was purified by chromatography over silica gel using ethyl acetate/petroleum ether as the eluent to afford desired compounds $6 \mathrm{i}$ and $7 \mathrm{~h}$.

\section{General procedure for synthesis} of compounds $6 \mathrm{j}-6 \mathrm{k}$ and $7 \mathrm{i}-7 \mathrm{k}$

To a stirred solution of compound 6 f or $7 \mathrm{e}$ (1.0 equiv) in tetrahydrofuran, acryloyl chloride, 3-chloropropionyl chloride, or benzoyl chloride (1.1 equiv) was added. After stirring at room temperature for 5 minutes, triethylamine $(0.5 \mathrm{~mL})$ was added, and then the mixture was stirred at room temperature for 2-4 hours. The solvent was then removed under vacuum. The residue was washed with brine and then extracted with ethyl acetate. The organic layer was dried over anhydrous magnesium sulfate and concentrated under vacuum. The solid was purified by chromatography over silica gel using ethyl acetate/petroleum ether as the eluent to afford desired compounds $6 \mathrm{j}-6 \mathrm{k}$ and $7 \mathrm{i}-7 \mathrm{k}$.

\section{General procedure for synthesis of compounds $8 \mathrm{a}-8 \mathrm{~h}$}

A reaction mixture of the various substituted amines (1.0 equiv) and 5-chloroisatin (1.0 equiv) in methanol was stirred at $60^{\circ} \mathrm{C}$ for $3-5$ hours. The solvent of the resulting mixture was then removed under vacuum. The residue was washed with brine, dried over anhydrous magnesium sulfate, and then filtrated. The solid was purified by chromatography over silica gel using ethyl acetate/petroleum ether as the eluent to give desired compounds $8 \mathrm{a}-8 \mathrm{~h}$.

The spectral data of new or unreported compounds are shown in the Supplementary materials.

\section{Quantitative structure-activity relationship analysis}

The methods and software programs used for quantitative structure-activity relationship (SAR) model establishment and analysis, including descriptor calculation and selection, multiple linear regression analysis, and related software programs, were described in our previous publication. ${ }^{30}$

\section{Animals}

Male C57BL/6 mice weighing 18-22 g were obtained from the Animal Center of Wenzhou Medical University (Wenzhou, People's Republic of China). Animals were housed at a constant room temperature, with a 12/12-hour light-dark cycle and fed with a standard rodent diet and water. The animals were acclimatized to the laboratory for at least 7 days before use in the experiments. Protocols involving the use of animals were approved by the Wenzhou Medical University Animal Policy and Welfare Committee (approval documents: 2009/APWC/0031).

\section{Reagents}

All starting materials and reagents for synthesis and LPS were purchased from Sigma-Aldrich Co, (St Louis, MO, USA). eBioscience (San Diego, CA, USA) was the source of mouse IL-6 enzyme-linked immunosorbent assay (ELISA) kit and mouse TNF- $\alpha$ ELISA kit.

\section{Cells}

Mouse RAW264.7 macrophages were obtained from the American Type Culture Collection (Manassas, VA, USA). RAW264.7 macrophages were incubated in Dulbecco's Modified Eagle's Medium (DMEM) (Gibco ${ }^{\circledR}$; Life Technologies, Carlsbad, CA, USA) supplemented with 10\% FBS (Gibco), $100 \mathrm{U} / \mathrm{mL}$ penicillin, and $100 \mathrm{mg} / \mathrm{mL}$ streptomycin at $37^{\circ} \mathrm{C}$ with $5 \% \mathrm{CO}_{2}$.

\section{Cell treatment and ELISA assay}

Mouse RAW264.7 macrophages were incubated in DMEM (Gibco) supplemented with 10\% FBS, $100 \mathrm{U} / \mathrm{mL}$ penicillin, and $100 \mu \mathrm{g} / \mathrm{mL}$ streptomycin at $37^{\circ} \mathrm{C}$ with $5 \% \mathrm{CO}_{2}$. 
Cells were pretreated with $10 \mu \mathrm{M}$ of compounds, or vehicle control for 2 hours, then treated with LPS $(0.5 \mu \mathrm{g} / \mathrm{mL})$ for 22 hours. After treatment, the culture media and cells were collected separately. The culture media collected were centrifuged at 1,000 rpm for 10 minutes. The levels of TNF- $\alpha$ and IL- 6 in the media were determined by ELISA using mouse TNF- $\alpha$ and mouse IL-6 ELISA Kits (eBioscience). After centrifugation, the supernatant was separated and stored at $-80^{\circ} \mathrm{C}$ until use. Cells were washed with phosphate buffered saline (PBS) and harvested with cell lysis buffer (Tris-HCl $20 \mathrm{mM}$, NP-40 [nonyl phenoxypolyethoxylethanol] $1 \%, \mathrm{NaCl}$ $150 \mathrm{mM}$, EDTA [ethylenediaminetetraacetic acid] $2 \mathrm{mM}$, $\mathrm{Na}_{3} \mathrm{VO}_{4} 200 \mathrm{mM}$, SDS [sodium dodecyl sulfate] 0.1\%, and $\mathrm{NaF} 20 \mathrm{mM}$ ). The mixed liquor was shaken vigorously for 10 minutes in lysis buffer at $0^{\circ} \mathrm{C}$. After being centrifuged at $12,000 \mathrm{rpm}$ for 5 minutes at $4^{\circ} \mathrm{C}$, the total protein was collected, and the concentrations were determined using Bio-Rad Laboratories Inc. (Hercules, CA, USA) protein assay reagents. The total amount of the inflammatory factor in the media was normalized to the total protein amount of the viable cell pellets.

\section{MTT assay}

RAW264.7 cells were seeded into 96-well plates at a density of 5,000 cells per well in DMEM (Gibco) supplemented with $10 \% \mathrm{FBS}, 100 \mathrm{U} / \mathrm{mL}$ penicillin, and $100 \mu \mathrm{g} / \mathrm{mL}$ streptomycin. The cells were maintained at $37^{\circ} \mathrm{C}$ in a humidified atmosphere containing 5\% $\mathrm{CO}_{2}$. All experiments were carried out 24 hours after cells were seeded. Tested compounds were dissolved in dimethyl sulfoxide (DMSO) and diluted with DMEM to the final concentrations of $10 \mu \mathrm{M}$ ( $1 \%$ DMSO). The cells were incubated with test compounds for 24 hours before the MTT assay. A fresh solution of MTT $(5 \mathrm{mg} / \mathrm{mL})$ prepared in PBS was added to each single well of the 96 -well plates. The plates were then incubated in a $\mathrm{CO}_{2}$ incubator for 4 hours, cells dissolved with $150 \mu \mathrm{L}$ DMSO, and then analyzed in a multi-well-plate reader at $570 \mathrm{nM}$. Active compounds $7 \mathrm{i}$ and 8 e were investigated for cytotoxic effects by using a higher concentration $(10,25$, and $50 \mu \mathrm{M})$.

\section{Real-time quantitative polymerase chain reaction}

Cells were homogenized in TRIZOL kit (Invitrogen; Thermo Fisher Scientific, Waltham, MA, USA) for extraction of RNA according to each manufacturer's protocol. Both reverse transcription and quantitative polymerase chain reaction (PCR) were carried out using a two-step M-MLV Platinum SYBR Green qPCR SuperMix-UDG kit (Invitrogen). Eppendorf (Hamburg, Germany) Mastercycler ep realplex detection system was used for quantitative PCR analysis. The primers of genes including COX-2, iNOS, and PGES were synthesized by Invitrogen. The primer sequences of mouse genes used were as follows:

COX-2 sense primer, 5'-TGGTGCCTGGTC TGATGATG-3'

COX-2 antisense primer, 5'-GTGGTAACCGCTCAGG TGTTG-3'

iNOS sense primer, 5'-CAGCTGGGCTGTACAAACCTT-3'

iNOS antisense primer, 5'-CATTGGAAGTGAAGCG TTTCG-3'

PGES sense primer, 5'-GAGCCCACCGCAACGACATG-3'

PGES antisense primer, 5'-CAGATGGTGGGCCA CCTCCC-3'

$\beta$-actin sense primer, 5'-TGGAATCCTGTGGCATC CATGAAAC-3'

$\beta$-actin antisense primer, 5'-TAAAACGCAGCTCA GTAACAGTCCG-3'.

The amount of each gene was determined and normalized by the amount of $\beta$-actin.

\section{LPS-induced inflammatory mortality in mice}

Male C57BL/6 mice were obtained from the Animal Center of Wenzhou Medical College (Wenzhou, People's Republic of China). Animals were housed at a constant room temperature, with a 12/12-hour light-dark cycle, and fed with a standard rodent diet and water. The animals were acclimatized to the laboratory for at least 7 days before use in the experiments. Protocols involving the use of animals were approved by the Wenzhou Medical College Animal Policy and Welfare Committee (Approval documents: 2009/APWC/0031). Compound 7i was firstly dissolved with macrogol 15 hydroxystearate (a nonionic solubilizer for injection, from BASF [Ludwigshafen, Germany]) with or without medium-chain triglycerides (MCT, from BASF) in a water bath at $37^{\circ} \mathrm{C}$. The concentration of $7 \mathrm{i}$ was $2 \mathrm{mg} / \mathrm{mL}$. The concentration of solubilizer was $5 \%-10 \%$, and MCT $0.5 \%-2.0 \%$ in final solution. For the vehicle, the mixture of solubilizer and MCT was prepared at $10 \%$ and 2\%, respectively. Male C57BL/6 mice weighing 18-22 g were treated with $7 \mathrm{i}$ solution $(200 \mu \mathrm{L}, 15 \mathrm{mg} / \mathrm{kg})$ by intravenous injection 15 minutes before the intraperitoneal injection of LPS (25 mg/kg). Control animals received a similar volume $(200 \mu \mathrm{L})$ of vehicle. Bodyweight change and mortality were recorded for 7 days.

\section{Statistical analysis}

The results are presented as the mean \pm standard deviation. The Student's $t$-test was employed to analyze the differences between sets of data. Statistics were performed using 
GraphPad Pro (GraphPad, San Diego, CA, USA). P-values less than 0.05 were considered indicative of significance. All experiments were repeated at least three times.

\section{Results and discussion Chemistry}

The facile and efficient synthetic route for 7-aza-2-oxindoles (6a-6k), indole-2-ones (7a-7k) and amino-linked indole-2-ones (8a-8h) is outlined in Figures 2 and 3. Treatment of hydroxybenzaldehyde with allyl bromide was catalyzed by $\mathrm{K}_{2} \mathrm{CO}_{3}$ in $\mathrm{CH}_{3} \mathrm{CN}$ to produce intermediates 1 and 2. Nucleophilic substitution of the fluorine atom of 4-fluorobenzaldehyde with $\mathrm{N}$-methylpiperazine, morpholine or piperazine gave intermediates 3,4 , and 5, respectively. Compounds $1-5$ and several substituted benzaldehydes were condensed with 7-aza-2-oxindole or indole-2-one through an aldol condensation reaction in basic conditions to produce compounds $6 \mathrm{a}-6 \mathrm{~h}$ and $7 \mathrm{a}-7 \mathrm{~g}$, with a yield ranging from $30 \%-80 \%$. Compounds $6 \mathrm{i}-6 \mathrm{k}$ and $7 \mathrm{~h}-7 \mathrm{k}$ were prepared by a one-step amidation reaction using $6 \mathrm{f}$ or $7 \mathrm{e}$ and acyl chloride with triethylamine as a catalyst, producing a yield of 30\%-60\% (Figure 2). The synthesis of amino-linked indole-2-one (8a-8h) proceeded via a different route (Figure 3). Briefly, commercially available 5-chloroisatin and aromatic amines were refluxed in methanol solution to afford the target amino-linked indole-2-ones (8a-8h). 6e, 7b-7d, and 7f-7h have been reported in the literature (see Supplementary material). All of the new products were determined using ${ }^{1} \mathrm{H}-\mathrm{NMR}$, ${ }^{13} \mathrm{C}-\mathrm{NMR}$ (Figure S1), and ESI-MS, and some of bioactive compounds were further characterized by HRMS and LC-MS (Figure S2). Detailed information on their synthesis and structural characterization are described in the Supplementary materials. Before use in the biological experiments, all synthetic compounds were purified by recrystallization or silica gel column chromatography, and high-performance liquid chromatography was used to determine their purity $(>95 \%)$ as shown in Figure S3.

\section{Cytokine-inhibitory activity and cytotoxicity of all compounds}

The cultured macrophage stimulated by LPS, a prototypical endotoxin in Gram-negative bacteria, was used to establish the inflammatory cell model. The anti-inflammatory

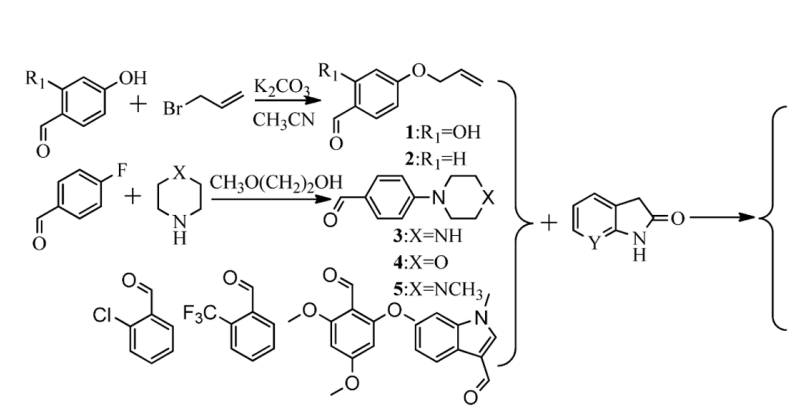

\begin{tabular}{|c|c|c|c|c|c|}
\hline Comp. & $\mathbf{Y}$ & $\mathbf{R}$ & Comp. & $\mathbf{Y}$ & $\mathbf{R}$ \\
\hline $6 a$ & $\mathrm{~N}$ & $\mathrm{R}_{2}=2-\mathrm{OH}, 4-\mathrm{OCH}_{2} \mathrm{CHCH}_{2}$ & $7 \mathbf{a}$ & $\mathrm{C}$ & $\mathrm{R}_{2}=2-\mathrm{OH}, 4-\mathrm{OCH}_{2} \mathrm{CHCH}_{2}$ \\
\hline $6 b$ & $\mathrm{~N}$ & $\mathrm{R}_{2}=4-\mathrm{OCH}_{2} \mathrm{CHCH}_{2}$ & $7 b$ & $\mathrm{C}$ & $\mathrm{R}_{2}=4-\mathrm{OCH}_{2} \mathrm{CHCH}_{2}$ \\
\hline $6 c$ & $\mathrm{~N}$ & $\mathrm{R}_{2}=2,4,6-\mathrm{OCH}_{3}$ & $7 \mathrm{c}$ & $\mathrm{C}$ & $\mathrm{R}_{2}=2,4,6-\mathrm{OCH}_{3}$ \\
\hline 6d & $\mathrm{N}$ & $\mathrm{R}_{2}=2-\mathrm{Cl}$ & $7 \mathbf{d}$ & $\mathrm{C}$ & $\mathrm{R}_{2}=2-\mathrm{CF}_{3}$ \\
\hline $6 e$ & $\mathrm{~N}$ & 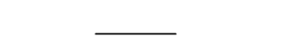 & $7 e$ & $\mathrm{C}$ & $\mathrm{R}_{2}=4-\mathrm{N}\left(\mathrm{CH}_{2} \mathrm{CH}_{2}\right)_{2} \mathrm{NH}$ \\
\hline $6 f$ & $\mathrm{~N}$ & $\mathrm{R}_{2}=4-\mathrm{N}\left(\mathrm{CH}_{2} \mathrm{CH}_{2}\right)_{2} \mathrm{NH}$ & $7 f$ & $\mathrm{C}$ & $\mathrm{R}_{2}=4-\mathrm{N}\left(\mathrm{CH}_{2} \mathrm{CH}_{2}\right)_{2} \mathrm{NCH}_{3}$ \\
\hline $6 \mathrm{~g}$ & $\mathrm{~N}$ & $\mathrm{R}_{2}=4-\mathrm{N}\left(\mathrm{CH}_{2} \mathrm{CH}_{2}\right)_{2} \mathrm{NCH}_{3}$ & $7 \mathrm{~g}$ & $\mathrm{C}$ & $\mathrm{R}_{2}=4-\mathrm{N}\left(\mathrm{CH}_{2} \mathrm{CH}_{2}\right)_{2} \mathrm{O}$ \\
\hline $6 h$ & $\mathrm{~N}$ & $\mathrm{R}_{2}=4-\mathrm{N}\left(\mathrm{CH}_{2} \mathrm{CH}_{2}\right)_{2} \mathrm{O}$ & $7 \mathrm{~h}$ & $\mathrm{C}$ & $\mathrm{R}_{3}=\mathrm{H}$ \\
\hline $6 \mathrm{i}$ & $\mathrm{N}$ & $\mathrm{R}_{3}=\mathrm{H}$ & $7 \mathbf{i}$ & $\mathrm{C}$ & $\mathrm{R}_{3}=\mathrm{CHCH}_{2}$ \\
\hline $6 j$ & $\mathrm{~N}$ & $\mathrm{R}_{3}=\mathrm{CHCH}_{2}$ & $7 \mathbf{j}$ & $\mathrm{C}$ & $\mathrm{R}_{3}=\mathrm{CH}_{2} \mathrm{CH}_{2} \mathrm{Cl}$ \\
\hline $6 \mathbf{k}$ & $\mathrm{N}$ & $\mathrm{R}_{3}=\mathrm{CH}_{2} \mathrm{CH}_{2} \mathrm{Cl}$ & $7 \mathbf{k}$ & $\mathrm{C}$ & $\mathrm{R}_{3}=\mathrm{Ph}$ \\
\hline
\end{tabular}

Figure 2 General synthetic routes and chemical structures of 7-aza-2-oxindoles (6a-6k) and indole-2-ones (7a-7k). 


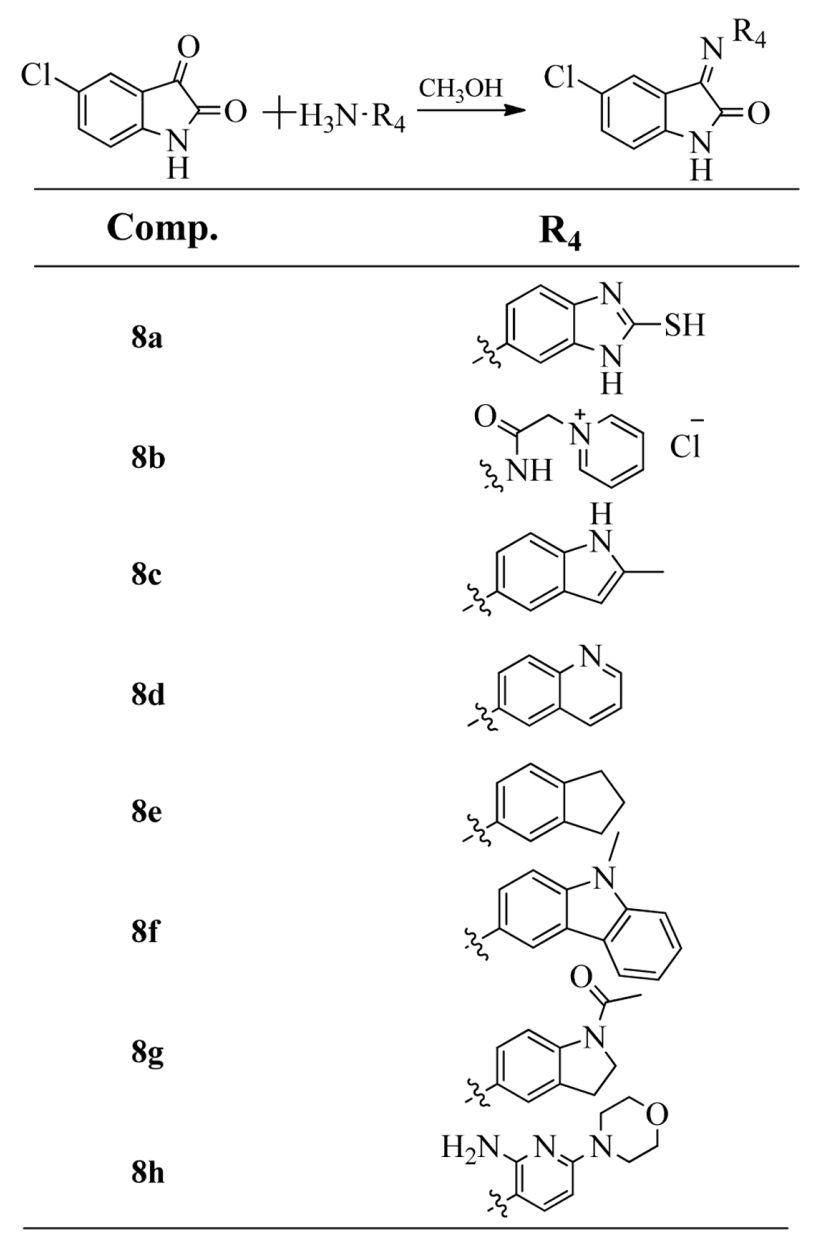

Figure 3 General synthetic route and chemical structures of amino-linked indole2-ones (8a-8h).

Abbreviation: Comp, compound.

activity of tenidap and 30 synthetic compounds was determined to evaluate the ability of inhibiting the TNF- $\alpha$ and IL-6 release stimulated by LPS in mouse RAW264.7 macrophages. Macrophages were pretreated with compounds $(10 \mu \mathrm{M})$ for 2 hours and then treated with LPS $(0.5 \mu \mathrm{g} / \mathrm{mL})$ for 22 hours. ELISA was employed to detect the cytokines in media, and the cytokine amounts were normalized by the protein concentration of cells in the same plates.

The preliminary screening results are shown in Figure 4A and B. The majority of the 30 tested compounds exhibited obvious anti-inflammatory activity by inhibiting LPS-induced TNF- $\alpha$ and IL-6 expression in vitro and showed a higher activity than the leading compound tenidap. Among these compounds, 7b, 7i, 8b, 8e, 8f, and 8g showed inhibition of IL-6 production in the range of $40 \%-50 \%$. Compounds $7 \mathrm{c}, 7 \mathrm{i}, 7 \mathrm{k}, 8 \mathrm{~d}$, and $8 \mathrm{e}$ exhibited more than $40 \%$ inhibition of TNF- $\alpha$ expression compared with LPS controls.
Compound $7 \mathrm{i}$ showed the strongest inhibitory activity on LPS-induced TNF- $\alpha$ and IL- 6 production, with inhibitory rates of $44.5 \%$ and $57.2 \%$, respectively. Before further investigation, the cytotoxicity of all compounds was tested in RAW264.7 cells. Cell viability was detected by MTT assay after treatment with the compounds for 24 hours. As shown in Figure 4C, only $6 \mathrm{c}$ and $7 \mathrm{c}$ showed moderate cytotoxicity, while the other compounds were nontoxic at $10 \mu \mathrm{M}$ in RAW264.7 cells, indicating that they are relatively safe.

\section{Quantitative SAR of these indole-2-one analogs}

According to the bio-screening result, it was observed that indole-2-ones $(7 \mathrm{a}-7 \mathrm{k})$ exhibited more potent antiinflammatory activity than 7-aza-2-oxindoles (6a-6k). Among these derivatives, $7 \mathrm{~b}, 7 \mathrm{i}, 7 \mathrm{c}$, and $7 \mathrm{k}$ with an electrondonating group at the phenyl ring exhibited strong antiinflammatory activity, while a decrease in anti-inflammatory activity is detected when the phenyl ring was substituted with the electron-withdrawing groups (ie, $6 \mathrm{~d}$ and $7 \mathrm{~d}$ ). In addition, an appropriate polarity of substituents also plays an important role in the cytokine-inhibitory effects of compounds. Further, a quantitative SAR was established to explore the SAR of these compounds and to assess the effects of different substituents on the anti-inflammatory activity. The results represented by the scatterplot of predicted versus experimental values are shown in Figure 5. Using three different variables, the statistically significant models (Equations 1 and 2 in Figure 5) were obtained for the anti-TNF- $\alpha$ and anti-IL- 6 activities of compounds, with relatively high regression coefficients $\left(R^{2}\right)$ of 0.73 and 0.77 , respectively. The quantitative SAR results indicate that the polarizability and lipid/water partition coefficient (ALogP) of the molecule may play a crucial role in the anti-inflammatory activity of indole-2-one derivatives. The analysis on SAR and quantitative SAR models contribute to pave the way for us to design and optimize anti-inflammatory candidates with the indole-2-one skeleton in the future.

\section{Cytotoxicity of the most active compounds $7 i$ and $8 e$}

We further tested the cytotoxic effects of the most promising compounds $7 \mathrm{i}$ and $8 \mathrm{e}$ at two higher concentrations (25, and $50 \mu \mathrm{M}$ ) in three normal cell lines: RAW264.7, mouse primary mouse peritoneal macrophages (MPMs), and rat renal tubular epithelial cell line NRK-52E. The results in Figure $\mathrm{S} 4$ suggested that $7 \mathrm{i}$ and $8 \mathrm{e}$ are not cytotoxic at these 


\section{A}

TNF- $\alpha$

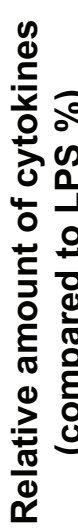

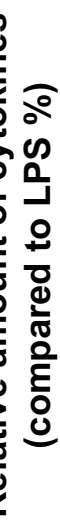

150

(1)

100

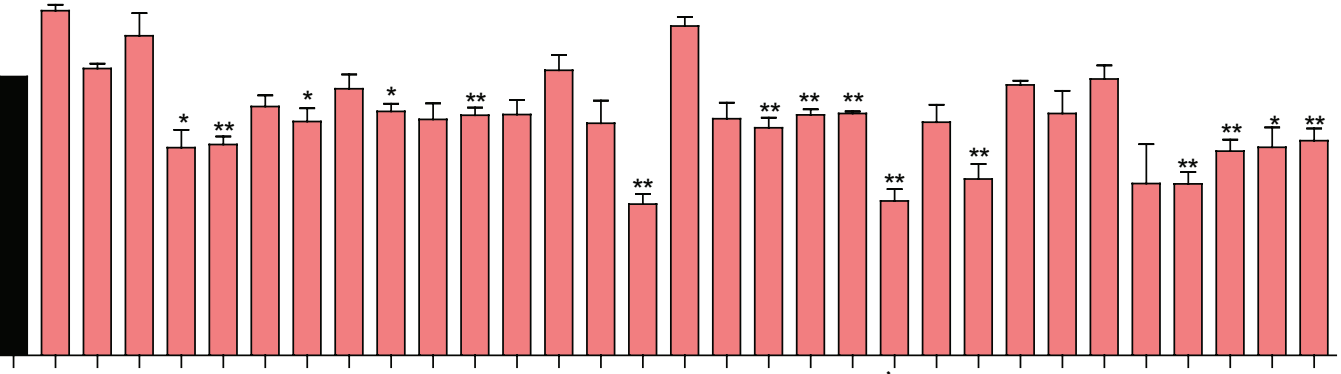

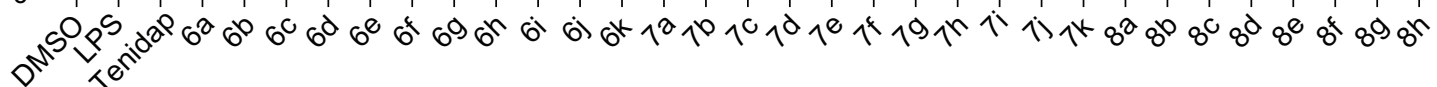

LPS $0.5 \mu \mathrm{g} / \mathrm{mL}$

B

IL-6

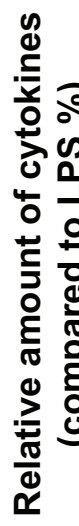

150

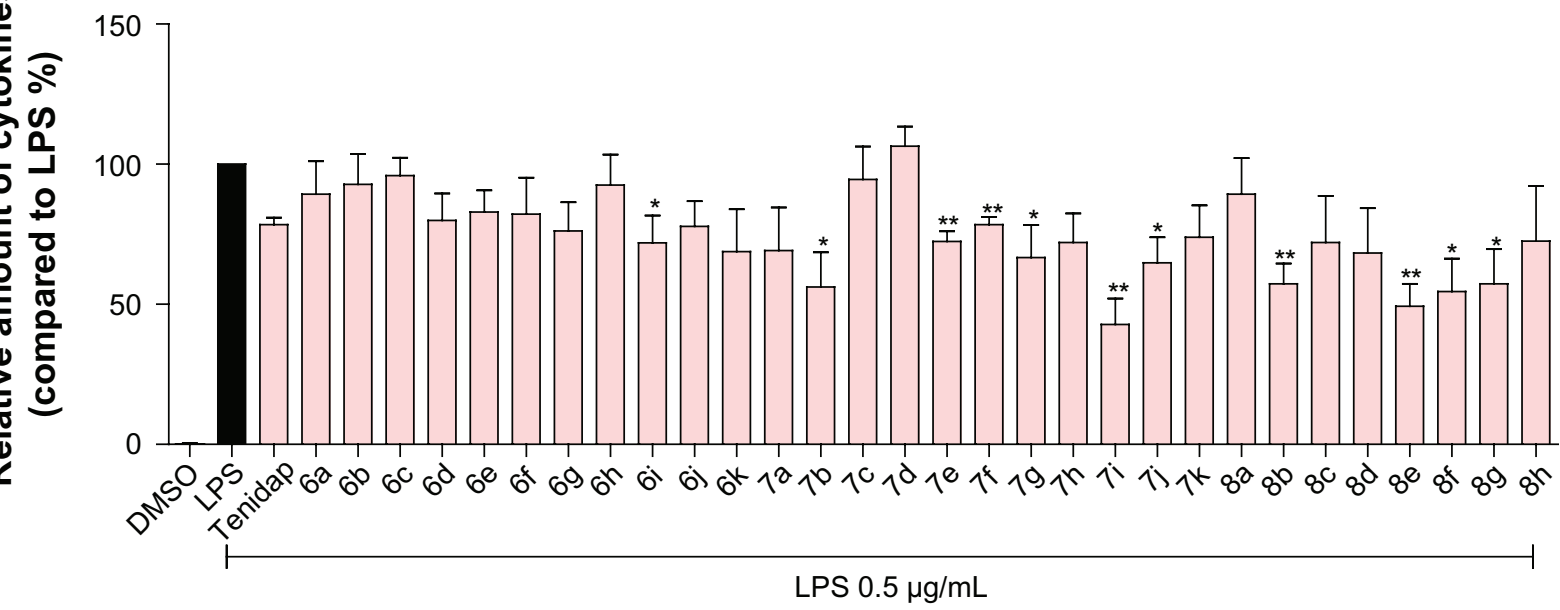

C

RAW 264.7

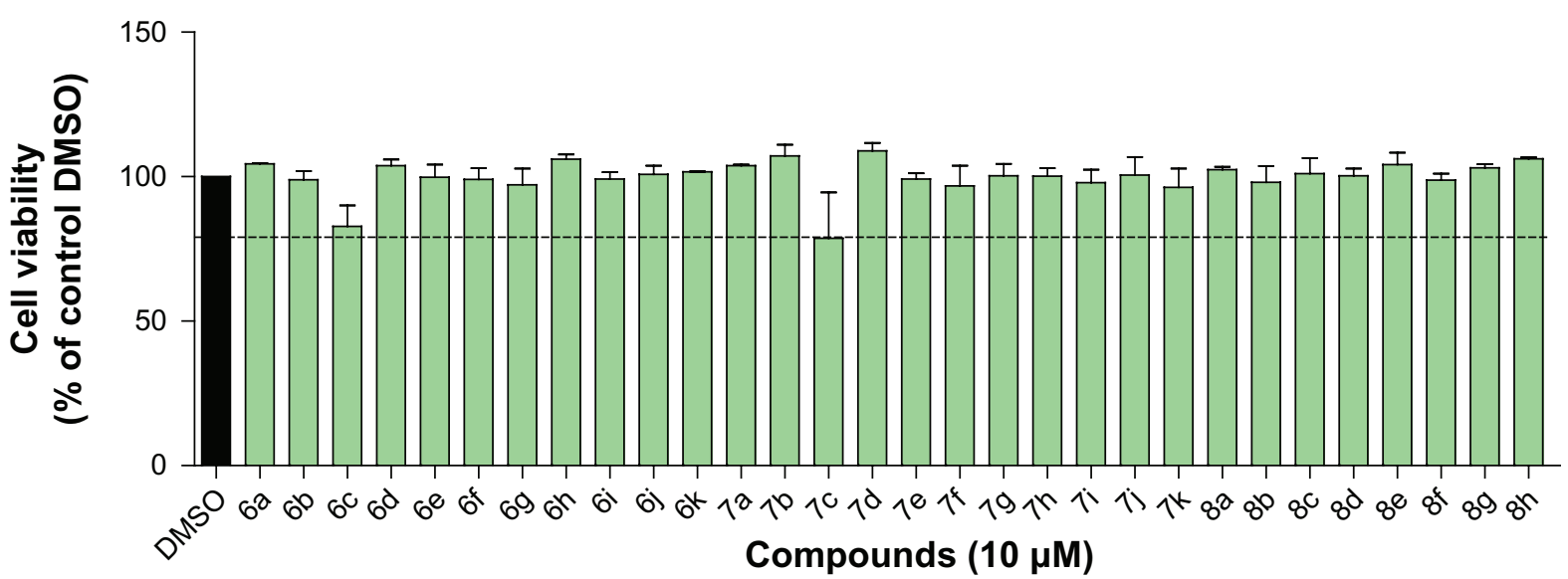

Figure 4 Cytokine-inhibitory activity and cytotoxicity of all compounds. (A and $\mathbf{B})$ Macrophages were pre-treated with compounds (I0 $\mu \mathrm{M})$ for 2 hours and then treated with LPS $(0.5 \mu \mathrm{g} / \mathrm{mL})$ for another 22 hours. TNF- $\alpha(\mathbf{A})$ and IL-6 (B) levels in the media were detected by ELISA and were normalized by the total protein. The results were expressed as the percentage of LPS control. Each bar represents mean \pm SEM of three independent experiments. $* P<0.05$; $* * P<0.01$. (C) The cytotoxicity of compounds $(10 \mu \mathrm{M})$ was tested in RAW264.7 macrophages. MTT method was employed for cell viability after a treatment period of 24 hours.

Abbreviations: DMSO, dimethyl sulfoxide; ELISA, enzyme-linked immunosorbent assay; IL, interleukin; LPS, lipopolysaccharide; MTT, methyl thiazolyl tetrazolium; SEM, standard error of the mean; TNF, tumor necrosis factor. 

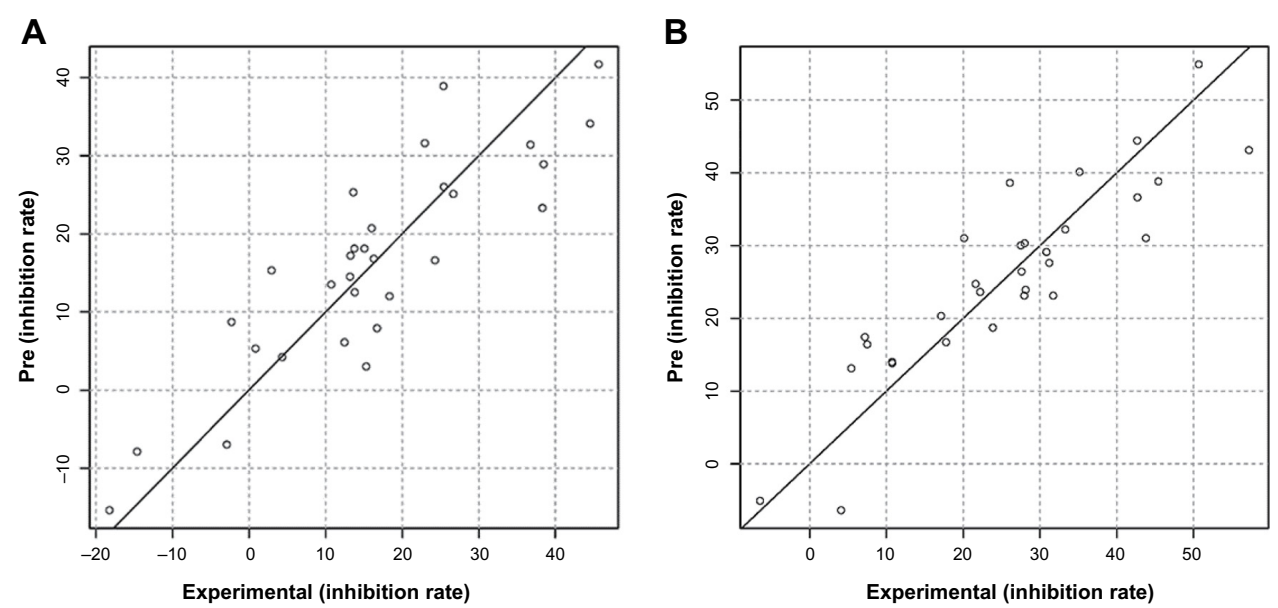

Figure 5 Plots of predicted activity against the corresponding experimental activity on TNF- $\alpha(\mathbf{A})^{\mathrm{a}}$ and IL-6 (B) $)^{\mathrm{b}}$ inhibition.

Notes: ${ }^{\mathrm{E} E q u a t i o n} \mathrm{I}, \mathrm{IR}_{\mathrm{TNF}-\alpha}=-29.37( \pm 10.18)+5.23( \pm 0.58) \mathrm{RDF}+339.82( \pm 44.57) \mathrm{H}-\mathrm{GETAWAY}-0.23( \pm 0.053) \mathrm{H}-\mathrm{GETAWAY}, \mathrm{N}=30, R^{2}=0.76, R_{\mathrm{adj}}{ }^{2}=0.73, s=8.03$, $F_{3,26}=27.29, P=3.42 \times 10^{-8}$; bequation $2, I_{\mathrm{lL}-6}=87.87( \pm 10.61)-67.92( \pm \mid 4.57)$ Geary $-0.43( \pm 0.12)$ RDF $+15.74( \pm 4.68) 3 D-M o R S E, N=30, R^{2}=0.79, R_{\text {adj }}^{2}=0.77, s=7.12$, $F_{3,26}=33.05, P=5.04 \times 10^{-9}$; ; where IR is the inhibition rate, $\mathrm{N}$ is the number of compounds taken into account in the regression, $R^{2}$ is the multiple correlation coefficient, $R_{\text {adj }}{ }^{2}$ is the adjusted multiple correlation coefficient, $s$, is the residual standard error, and the $F$ value is related to the $F$-statistic analysis (Fischer's exact test); the numbers in parentheses mean the standard deviation of the coefficients.

Abbreviations: 3D-MoRSE, 3D-Molecule Representation of Structures based on Electron diffraction; Geary, Geary topological autocorrelation descriptors; GETAWAY, GEometry, Topology and Atom-Weights AssemblY descriptors; IL, interleukin; Pre, predicted; RDF, radial distribution function; TNF, tumor necrosis factor.

concentrations. It is noteworthy that the structure of compound $7 \mathrm{i}$ contains two amide-based Michael addition acceptors ( $\alpha, \beta$-unsaturated ketone), which have been commonly considered to contribute to the side-effects of small-molecule agents. Although Michael addition acceptors are traditionally shunned in modern drug discovery, trapping of thiols by covalent coupling represents an important mechanism of bioactivity, and many biologically relevant and druggable pathways are targeted by thiol-reactive compounds. ${ }^{31}$ Recently, a number of papers have also suggested that amide-based Michael acceptors might provide tolerable drugs. ${ }^{32,33}$ The fact that compound $7 \mathrm{i}$ with two $\alpha, \beta$-unsaturated ketone moieties shows excellent anti-inflammatory effects but noncytotoxicity may indicate that the compound may participate in a facile Michael addition. ${ }^{34}$ In addition, it is also unclear whether the Michael addition receptor plays an important role in the anti-inflammatory properties of these indole-2ones. Thus, further studies are necessary to establish such a notion. Such studies should include testing of the antiinflammatory activity of newly designed derivatives, with or without Michael addition receptors, and examination of their underlying molecular mechanisms and targets.

\section{Compounds $7 \mathrm{i}$ and $8 \mathrm{e}$ inhibited the LPS-induced cytokine release in a dose-dependent manner}

Dose-dependent inhibitory activity of $7 \mathrm{i}$ and 8e were further assessed. RAW264.7 macrophages were pretreated with $7 \mathrm{i}$ and $8 \mathrm{e}$ at concentrations of $2.5,5.0,10$, and $20 \mu \mathrm{M}$ for 2 hours, respectively, and were subsequently incubated with LPS $(0.5 \mu \mathrm{g} / \mathrm{mL})$ for 22 hours. The release of TNF- $\alpha$ and IL- 6 was determined by ELISA. As shown in Figure $6 \mathrm{~A}$ and $\mathrm{B}$, compounds $7 \mathrm{i}$ and 8e exhibited dosedependent inhibition against LPS-stimulated TNF- $\alpha$ and IL-6 releases. Compound 7i showed stronger inhibitory rates than $8 \mathrm{e}$.

\section{Compounds 7i and 8e inhibited the LPS-stimulated mRNA expression of mediators COX-2, PGES, and iNOS}

Since the COX-2 pathway has been reported to be involved in tenidap's anti-inflammatory effects, we also demonstrated the inhibitory effects of tenidap, $7 \mathrm{i}$, and $8 \mathrm{e}$ against the overexpression of mediators COX-2, PGES, and iNOS by real-time quantitative PCR in LPS-stimulated macrophages. Here, close to the pathological practice, we used the mouse primary mouse peritoneal macrophages (MPMs) instead of the macrophage cell line RAW264.7. Briefly, primary macrophages were treated with compounds $(10 \mu \mathrm{M})$ and LPS $(0.5 \mu \mathrm{g} / \mathrm{mL})$, and total RNA was extracted. Specific mRNAs were detected by real-time quantitative PCR. The results in Figure 7 show that 8e had a comparable inhibition to tenidap, while $7 \mathrm{i}$ possessed much higher activity than tenidap against COX-2, PGES, and iNOS expression. Thus, compound $7 \mathrm{i}$ was chosen for the next in vivo evaluation as an anti-inflammatory agent. 

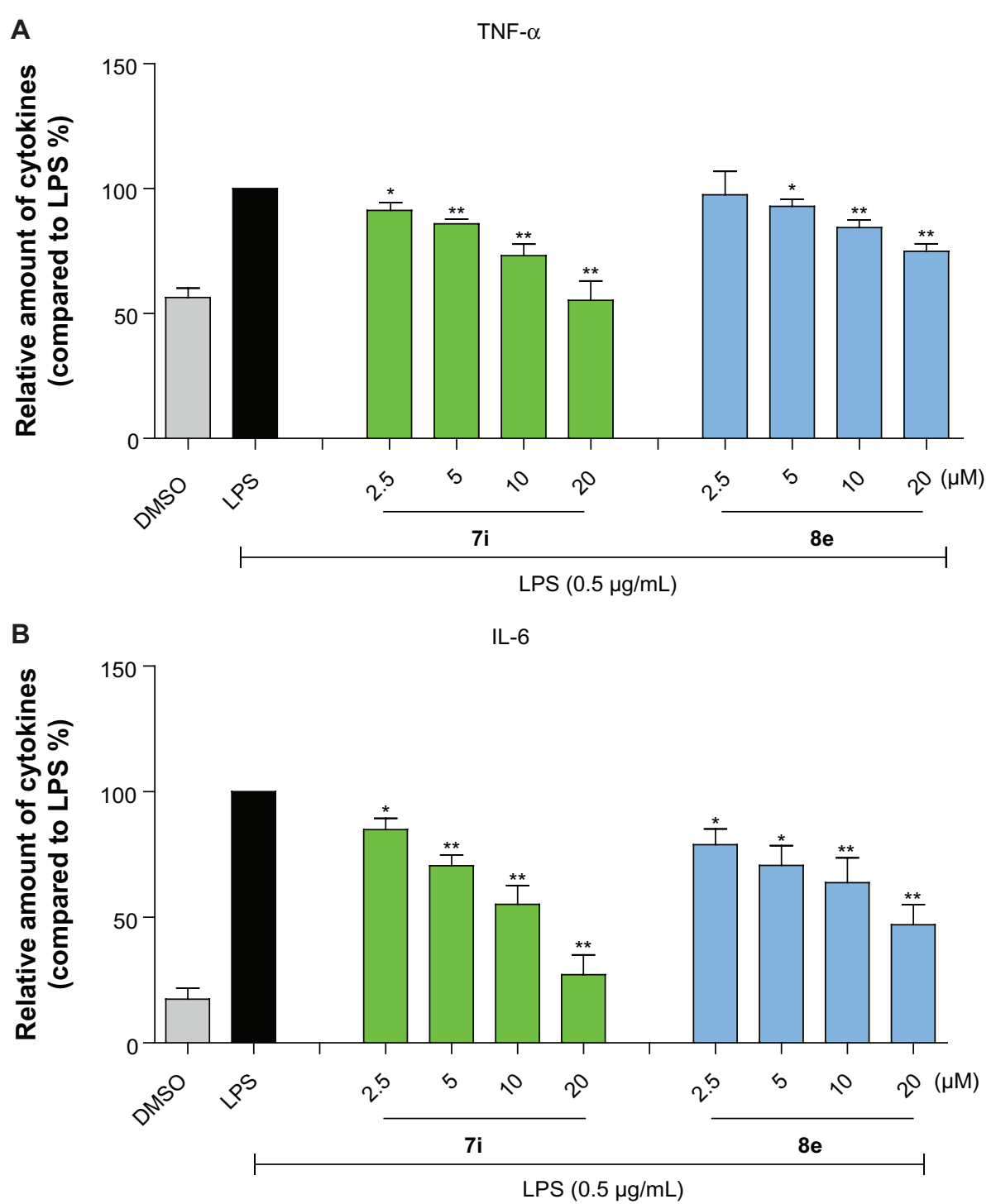

Figure 6 Dose-dependent inhibition of 7i and 8e on TNF- $\alpha$ and IL-6 secretion induced by LPS in RAW264.7 macrophages. Macrophages were pretreated with 7i and 8e at indicated concentrations for 2 hours, followed by $0.5 \mu \mathrm{g} / \mathrm{mL}$ LPS treatment for 22 hours. TNF- $\alpha$ (A) and IL-6 (B) levels in the culture medium were measured by ELISA and were normalized to the total protein amount. Each bar represents mean \pm SEM of three independent experiments. Statistical significance relative to LPS is indicated: $* P<0.05$; $* * P<0.01$.

Abbreviations: DMSO, dimethyl sulfoxide; ELISA, enzyme linked immunosorbent assay; LPS, lipopolysaccharide; SEM, standard error of the mean; TNF, tumor necrosis factor; IL, interleukin.
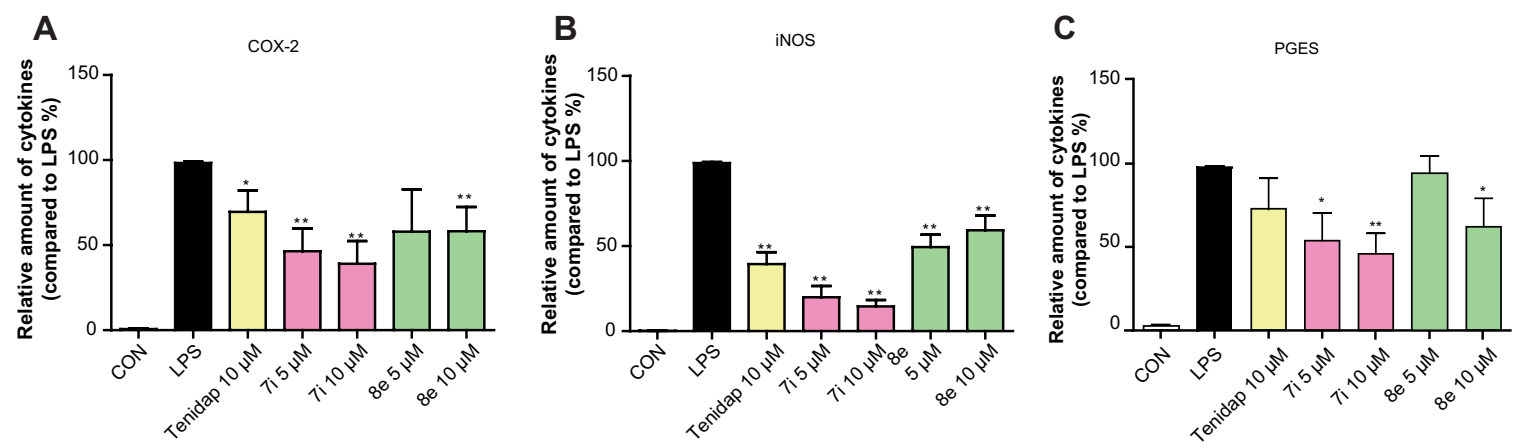

Figure 7 The inhibitory effects of tenidap, 7i, and $8 \mathrm{e}$ against the overexpression of mediators COX-2 (A), iNOS (B), and PGES (C) by real-time quantitative PCR in LPS-stimulated macrophages. Cells were pretreated with compounds or vehicle control for 2 hours and treated with LPS $(0.5 \mu \mathrm{g} / \mathrm{mL})$ for 6 hours. The mRNA levels of inflammatory mediators COX-2, PGES, and iNOS were quantified by real-time quantitative PCR. The mRNA values for each gene were normalized to internal control $\beta$-actin mRNA and were expressed as a ratio to DMSO.

Notes: Each bar represents the mean \pm SEM of four to seven independent experiments. Statistical significance relative to LPS group is indicated: $* P<0.05 ; * * P<0.0$ I.

Abbreviations: CON, control; COX-2, cyclooxygenase-2; DMSO, dimethyl sulfoxide; iNOS, inducible nitric oxide synthase; LPS, lipopolysaccharide; mRNA, messenger ribonucleic acid; PCR, polymerase chain reaction; PGES, prostaglandin E synthase; SEM, standard error of the mean. 


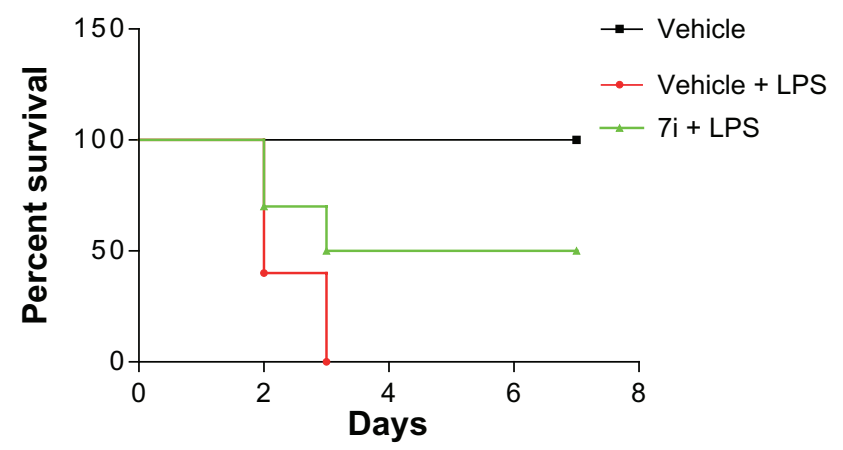

Figure 8 Active compound 7i attenuated LPS-induced septic shock in vivo. Mice were treated with $15 \mathrm{mg} / \mathrm{kg} 7 \mathrm{i}$ (intravenously) either 15 minutes before the injection of $25 \mathrm{mg} / \mathrm{kg}$ of LPS (intraperitoneally). Survival was recorded for 7 days after the LPS injection at the interval of I day.

Note: $\mathrm{n}=10$ animals in each group.

Abbreviation: LPS, lipopolysaccharide.

\section{Compounds 7i and 8e inhibited LPS-induced mortality}

As a major endotoxin, LPS has been implicated as a major cause of sepsis. Inflammatory shock as a consequence of LPS stimulation remains a serious clinical concern, which can cause a variety of pathologies ranging from mild (fever) to lethal (septic shock, organ failure, and death). ${ }^{35} \mathrm{We}$ determined whether $7 \mathrm{i}$ was able to attenuate endotoxininduced septic shock in vivo. Compound $7 \mathrm{i}$ was used in a water-soluble preparation for intravenous administration in acute inflammatory mouse models. LPS was intraperitoneally injected into 15-18-week-old mice at a dosage of $25 \mathrm{mg} / \mathrm{kg}$, with or without $7 \mathrm{i}$, and the survival was then monitored for 7 days. As shown in Figure 8, all animals treated with LPS alone died within 3 days as a result of septic shock. In animals receiving $7 \mathrm{i}$ at $15 \mathrm{mg} / \mathrm{kg} 15$ minutes prior to LPS injection, the survival was significantly increased compared with that of the control group ( $50 \%$ survival versus LPS-alone group, $P<0.01)$. Thus, our data provide evidence for the antiinflammatory effects of these indole-2-one derivatives and the potent preventative effects of $7 \mathrm{i}$ in sepsis.

\section{Conclusion}

In conclusion, we have presented 30 indole-2-one and 7-aza2-oxindole derivatives and evaluated their bioactivities in vitro as anti-inflammatory agents. It was observed that the indole-2-one series showed greater activity than the 7-aza2-oxindole series. Combined with the quantitative SAR analysis, the high molecular polarizability and low lipid/ water partition coefficient $(\mathrm{ALogP})$ in the indole-2-one skeleton were favorable for the anti-inflammatory activities of indole-2-one derivatives. Among tested compounds, $7 \mathrm{i}$ was the most potent one and showed excellent inhibition on the expression of TNF- $\alpha$, IL-6, COX-2, PGES, and iNOS in LPS-stimulated macrophages. In vivo, 7 i showed significant pharmacological effect in attenuation of the lethality of LPSinduced septic mouse models. These results indicate that indole-2-one derivatives are promising anti-inflammatory agents and should be further developed as candidates for the treatment of acute inflammatory diseases.

\section{Acknowledgments}

Financial support was provided by the National Natural Science Funding of China (21272179 and 21202124), High-level Innovative Talent Funding of Zhejiang Department of Health (GL), Project of Wenzhou Sci\&Tech Bureau (Y20120061), Zhejiang Natural Science Funding (Q12H300009), Qianjiang Talent Project of Zhejiang Province (2013R10020), the project sponsored by SRF for ROCS and SEM, and Zhejiang Key Group Project in Scientific Innovation (2010R50042 to TD).

\section{Disclosure}

The authors report no conflicts of interest in this work.

\section{References}

1. Angus DC, van der Poll T. Severe sepsis and septic shock. $N$ Engl J Med. 2013;369(9):840-851.

2. Marshall JC, Reinhart K. The Global Sepsis Alliance: building new collaborations to confront an under-recognized threat. Surg Infect (Larchmt). 2011;12(1):1-2.

3. Opal SM, Laterre PF, Francois B, et al. Effect of eritoran, an antagonist of MD2-TLR4, on mortality in patients with severe sepsis: the ACCESS randomized trial. JAMA. 2013;309(11):1154-1162.

4. Sutherland A, Thomas M, Brandon RA, et al. Development and validation of a novel molecular biomarker diagnostic test for the early detection of sepsis. Crit Care. 2011;15(3):R149.

5. Wheeler DS, Zingarelli B, Wheeler WJ, Wong HR. Novel pharmacologic approaches to the management of sepsis: targeting the host inflammatory response. Recent Pat Inflamm Allergy Drug Discov. 2009;3(2):96-112.

6. Ivady B, Beres BJ, Szabo D. Recent advances in sepsis research: novel biomarkers and therapeutic targets. Curr Med Chem. 2011;18(21): 3211-3225

7. Koh KB, Lee YJ, Beyn KM, Chu SH, Kim DM, Seo WY. Effects of high and low stress on proinflammatory and antiinflammatory cytokines. Psychophysiology. 2012;49(9):1290-1297.

8. Trenova AG, Manova MG, Kostadinova II, et al. Clinical and laboratory study of pro-inflammatory and antiinflammatory cytokines in women with multiple sclerosis. Folia Med (Plovdiv). 2011;53(2): 29-35.

9. Papadakis KA, Targan SR. Tumor necrosis factor: biology and therapeutic inhibitors. Gastroenterology. 2000;119(4):1148-1157.

10. Krishnamoorthy S, Honn KV. Inflammation and disease progression. Cancer Metastasis Rev. 2006;25(3):481-491.

11. Raj DS, Carrero JJ, Shah VO, et al. Soluble CD14 levels, interleukin 6, and mortality among prevalent hemodialysis patients. Am J Kidney Dis. 2009;54(6):1072-1080 
12. Paulose-Ram R, Hirsch R, Dillon C, Gu Q. Frequent monthly use of selected non-prescription and prescription non-narcotic analgesics among US adults. Pharmacoepidemiol Drug Saf. 2005;14(4):257-266.

13. Bernard GR, Wheeler AP, Russell JA, et al. The effects of ibuprofen on the physiology and survival of patients with sepsis. The Ibuprofen in Sepsis Study Group. N Engl J Med. 1997;336(13):912-918.

14. Winning J, Neumann J, Kohl M, et al. Antiplatelet drugs and outcome in mixed admissions to an intensive care unit. Crit Care Med. 2010;38(1): 32-37.

15. Eisen DP, Reid D, McBryde ES. Acetyl salicylic acid usage and mortality in critically ill patients with the systemic inflammatory response syndrome and sepsis. Crit Care Med. 2012;40(6):1761-1767.

16. Eisen DP. Manifold beneficial effects of acetyl salicylic acid and nonsteroidal anti-inflammatory drugs on sepsis. Intensive Care Med. 2012;38(8):1249-1257.

17. Wolfe MM, Lichtenstein DR, Singh G. Gastrointestinal toxicity of nonsteroidal antiinflammatory drugs. $N$ Engl J Med. 1999;340(24): 1888-1899.

18. Bresalier RS, Sandler RS, Quan H, et al. Cardiovascular events associated with rofecoxib in a colorectal adenoma chemoprevention trial. N Engl J Med. 2005;352(11):1092-1102.

19. Dinarello CA. Anti-inflammatory agents: present and future. Cell. 2010;140(6):935-950.

20. Syggelos SA, Giannopoulou E, Gouvousis PA, Andonopoulos AP, Aletras AJ, Panagiotopoulos E. In vitro effects of non-steroidal antiinflammatory drugs on cytokine, prostanoid and matrix metalloproteinase production by interface membranes from loose hip or knee endoprostheses. Osteoarthritis Cartilage. 2007;15(5):531-542.

21. Blanco Codesido M, Tesainer Brunetto A, Frentzas S, et al. Outcomes of patients with metastatic melanoma treated with molecularly targeted agents in phase I clinical trials. Oncology. 2011;81(2):135-140.

22. Wang Y, Xiao J, Zhou H, et al. A novel monocarbonyl analogue of curcumin, (1E,4E)-1,5-bis(2,3-dimethoxyphenyl)penta-1,4-dien-3-one, induced cancer cell $\mathrm{H} 460$ apoptosis via activation of endoplasmic reticulum stress signaling pathway. J Med Chem. 2011;54(11):3768-3778.

23. Wu J, Li J, Cai Y, et al. Evaluation and discovery of novel synthetic chalcone derivatives as anti-inflammatory agents. J Med Chem. 2011;54(23):8110-8123.

24. Liang G, Zhou H, Wang Y, et al. Inhibition of LPS-induced production of inflammatory factors in the macrophages by mono-carbonyl analogues of curcumin. J Cell Mol Med. 2009;13(9B):3370-3379.
25. Lai Y, Ma L, Huang W, et al. Synthesis and biological evaluation of 3-[4-(amino/methylsulfonyl)phenyl]methylene-indolin-2-one derivatives as novel COX-1/2 and 5-LOX inhibitors. Bioorg Med Chem Lett. 2010;20(24):7349-7353.

26. Wilhelm F, Kirby D, Kraska A, et al. Tenidap (TEN) vs piroxicam (PIR) vs piroxicam plus hydroxychloroquine (PIR/HCQ) in rheumatoid arthritis (RA): results of a two-year trial. Arthritis Rheum. 1994; 37(Suppl 9):S336.

27. Breedveld F. Tenidap: a novel cytokine-modulating antirheumatic drug for the treatment of rheumatoid arthritis. Scand J Rheumatol Suppl. 1994;100:31-44.

28. Nelson SD. Structure toxicity relationships - how useful are they in predicting toxicities of new drugs? In: Dansette PM, Snyder R, and Delaforge M, et al, editors. Biological Reactive Intermediates VI. New York: Springer; 2001:33-43.

29. Fouda HG, Avery MJ, Dalvie D, Falkner FC, Melvin LS, Ronfeld RA. Disposition and metabolism of tenidap in the rat. Drug Metab Dispos. 1997;25(2):140-148.

30. Chen G, Liu Z, Zhang Y, et al. Synthesis and anti-inflammatory evaluation of novel benzimidazole and imidazopyridine derivatives. ACS Med Chem Lett. 2012;4(1):69-74.

31. Amslinger $\mathrm{S}$. The tunable functionality of $\alpha, \beta$-unsaturated carbonyl compounds enables their differential application in biological systems. ChemMedChem. 2010;5(3):351-356.

32. Johansson MH. Reversible Michael additions: covalent inhibitors and prodrugs. Mini Rev Med Chem. 2012;12(13):1330-1344.

33. Klutchko SR, Zhou H, Winters RT, et al. Tyrosine kinase inhibitors. 19. 6-Alkynamides of 4-anilinoquinazolines and 4-anilinopyrido [3, 4-d] pyrimidines as irreversible inhibitors of the erbB family of tyrosine kinase receptors. J Med Chem. 2006;49(4):1475-1485.

34. Avonto C, Taglialatela-Scafati O, Pollastro F, et al. An NMR spectroscopic method to identify and classify thiol-trapping agents: revival of Michael acceptors for drug discovery? Angew Chem Int Ed Engl. 2011;50(2):467-471.

35. Leon CG, Tory R, Jia J, Sivak O, Wasan KM. Discovery and development of toll-like receptor 4 (TLR4) antagonists: a new paradigm for treating sepsis and other diseases. Pharm Res. 2008;25(8):1751-1761. 


\section{Supplementary materials}

The spectral data of new or unreported compounds

(Z)-3-[4-(allyloxy)-2-hydroxybenzylidene]-1 $H$-pyrrolo[2,3-b]pyridin-2(3H)-one (6a): Yellow powder, 32.2\% yield, mp: $212.5^{\circ} \mathrm{C}-213.3^{\circ} \mathrm{C} .{ }^{1} \mathrm{H}-\mathrm{NMR}\left(600 \mathrm{MHz}, \mathrm{DMSO}-d_{6}\right) \delta(\mathrm{ppm}): 4.67\left(2 \mathrm{H}, \mathrm{d}, J=6.6 \mathrm{~Hz}, \mathrm{O}-\mathrm{CH}_{2}\right), 5.29\left(1 \mathrm{H}, \mathrm{dd}, J_{1}=1.8\right.$ $\left.\mathrm{Hz}, J_{2}=10.2 \mathrm{~Hz},-\mathrm{C}=\mathrm{CH}_{2}\right), 5.44\left(1 \mathrm{H}, \mathrm{dd}, J_{1}=1.8 \mathrm{~Hz}, J_{2}=17.4 \mathrm{~Hz},-\mathrm{C}=\mathrm{CH}_{2}\right), 6.04-6.07(1 \mathrm{H}, \mathrm{m},-\mathrm{CH}=\mathrm{C}), 6.72(1 \mathrm{H}, \mathrm{d}$, $\left.J=8.4 \mathrm{~Hz}, \mathrm{Ar}-\mathrm{H}^{5}\right), 6.74\left(1 \mathrm{H}, \mathrm{s}, \mathrm{Ar}-\mathrm{H}^{3}\right), 6.89-6.91\left(1 \mathrm{H}, \mathrm{m}, 7\right.$-aza-2-oxindole- $\left.\mathrm{H}^{5}\right), 7.67\left(1 \mathrm{H}, \mathrm{d}, J=8.4 \mathrm{~Hz}, 7\right.$-aza-2-oxindole- $\left.\mathrm{H}^{4}\right)$, $7.77\left(1 \mathrm{H}, \mathrm{d}, J=8.4 \mathrm{~Hz}, 7\right.$-aza-2-oxindole- $\left.\mathrm{H}^{6}\right), 7.86\left(1 \mathrm{H}, \mathrm{d}, J=8.4 \mathrm{~Hz}, \mathrm{Ar}-\mathrm{H}^{6}\right), 7.98(1 \mathrm{H}, \mathrm{s}, \mathrm{Ar}-\mathrm{CH}) .{ }^{13} \mathrm{C}-\mathrm{NMR}(600 \mathrm{MHz}$, DMSO- $\left.d_{6}\right) \delta(\mathrm{ppm}): 168.76,162.08,158.67,156.72,156.65,147.62,133.49,131.19,129.12,123.79,118.16,117.44$, $115.55,106.83,104.91,100.45,69.04$. ESI-MS $m / z: 293.5(\mathrm{M}-1)^{-}$.

A

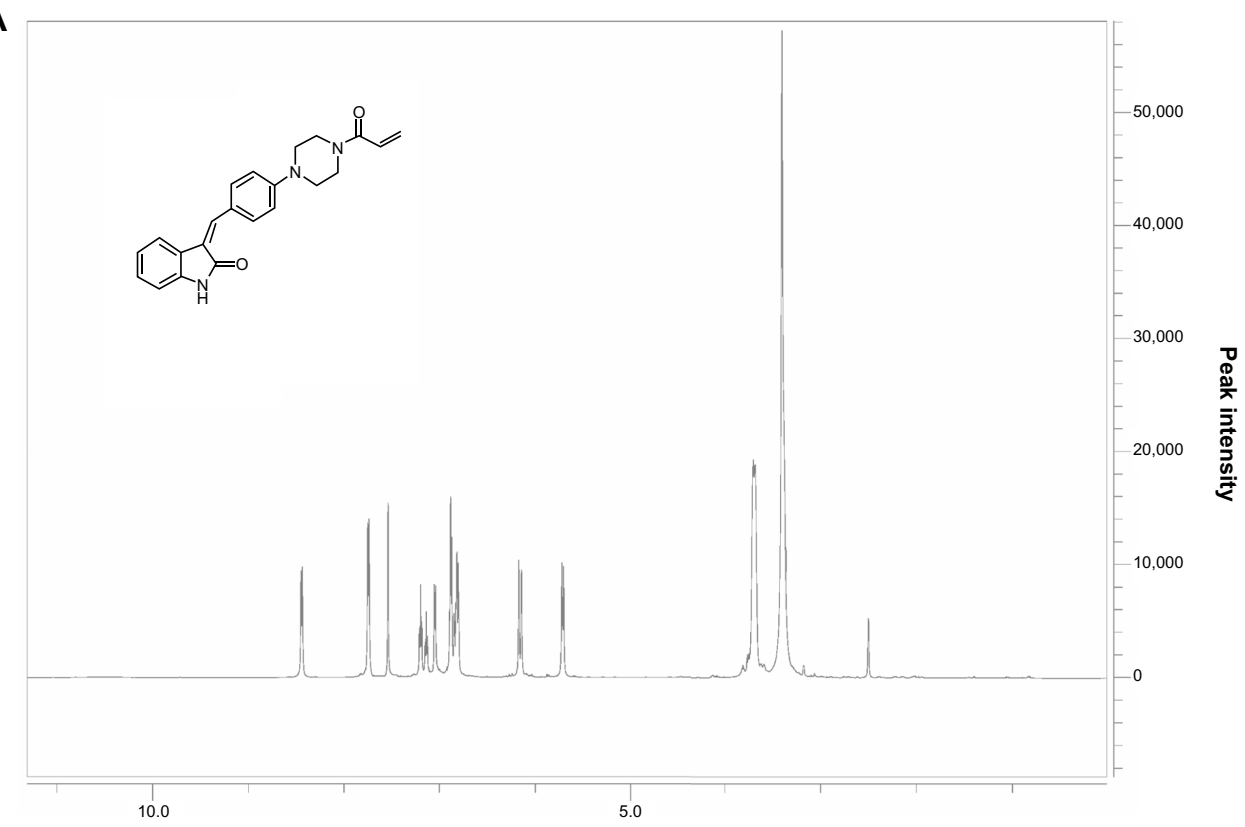

$\operatorname{ppm}(\mathbf{t} 1)$

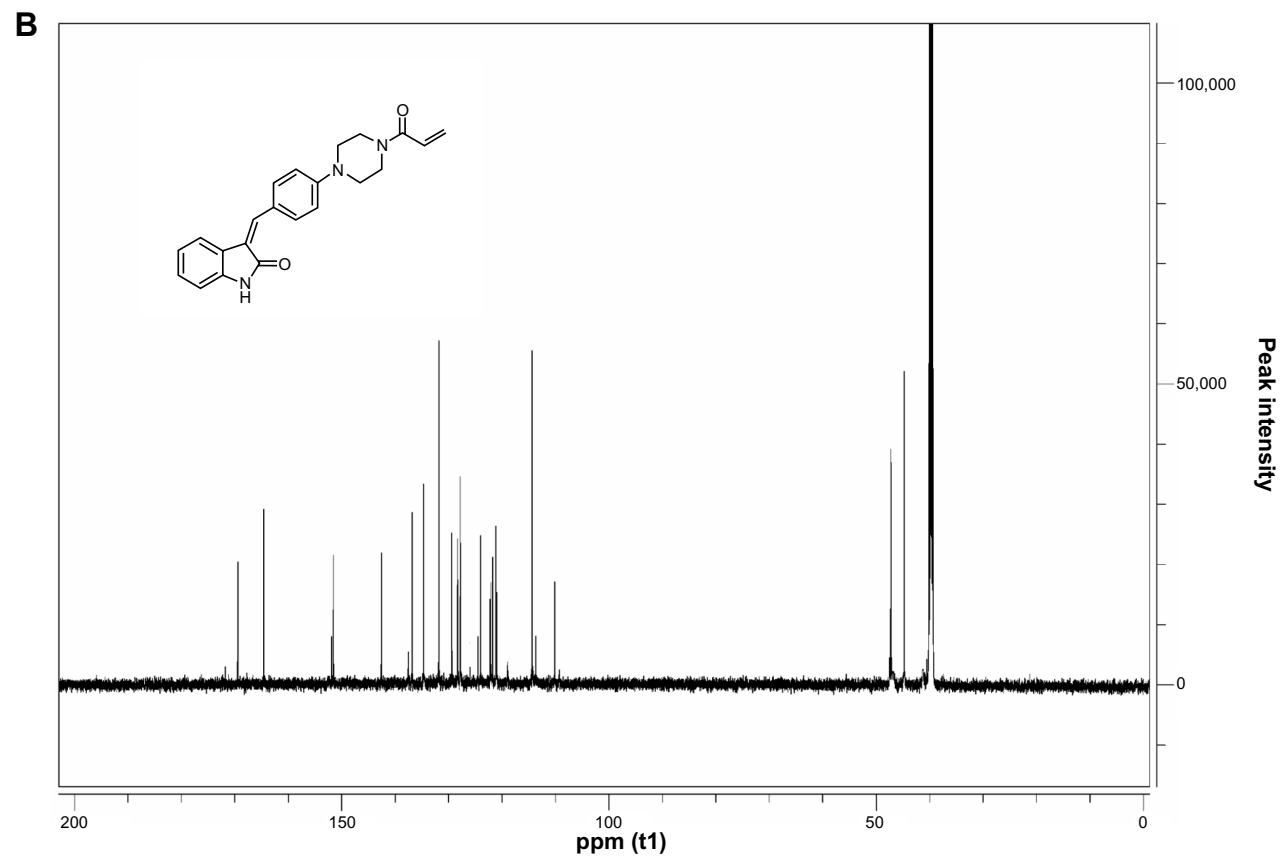




\section{C}
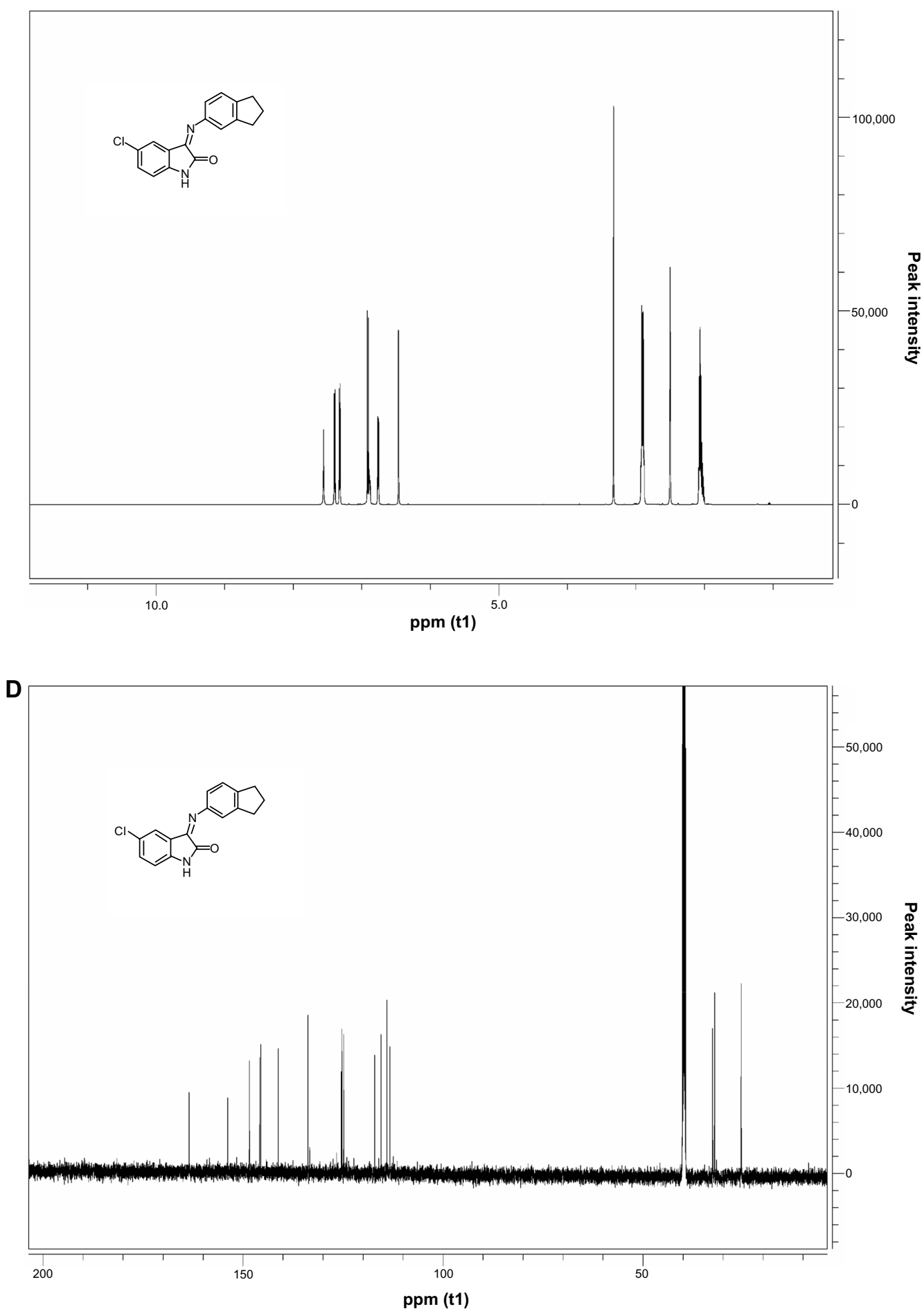

Figure SI Original spectrums of 'H-NMRand ${ }^{13} \mathrm{C}-\mathrm{NMR}$ data of the active compounds.

Notes: (A) 'H-NMR of compound 7i. (B) ${ }^{13} \mathrm{C}-\mathrm{NMR}$ of compound 7i. (C) ${ }^{1} \mathrm{H}-\mathrm{NMR}$ of compound 8e. (D) ${ }^{13} \mathrm{C}-\mathrm{NMR}$ of compound 8e.

Abbreviations: 'H-NMR, 'H-nuclear magnetic resonance; ${ }^{13} \mathrm{C}-\mathrm{NMR},{ }^{13} \mathrm{C}$-nuclear magnetic resonance; ppm, parts per million; $\mathrm{tl}$, relaxation time. 
(Z)-3-[4-(allyloxy)benzylidene]-1 $\boldsymbol{H}$-pyrrolo[2,3-b]pyridin-2(3H)-one (6b): Yellow powder, 30.4\% yield, mp: $135.6^{\circ} \mathrm{C}-136.9^{\circ} \mathrm{C} .{ }^{1} \mathrm{H}-\mathrm{NMR}\left(600 \mathrm{MHz}, \mathrm{DMSO}-d_{6}\right) \delta(\mathrm{ppm}): 4.67\left(2 \mathrm{H}, \mathrm{d}, J=4.8 \mathrm{~Hz}, \mathrm{O}-\mathrm{CH}_{2}\right), 5.30\left(1 \mathrm{H}, \mathrm{dd}, J_{1}=1.8 \mathrm{~Hz}\right.$, $\left.J_{2}=10.2 \mathrm{~Hz},-\mathrm{C}=\mathrm{CH}_{2}\right), 5.44\left(1 \mathrm{H}, \mathrm{dd}, J_{1}=1.8 \mathrm{~Hz}, J_{2}=17.4 \mathrm{~Hz},-\mathrm{C}=\mathrm{CH}_{2}\right), 6.04-6.10(1 \mathrm{H}, \mathrm{m},-\mathrm{CH}=\mathrm{C}), 6.91-6.93(1 \mathrm{H}, \mathrm{m}$, 7-aza-2-oxindole- $\left.\mathrm{H}^{5}\right), 7.12\left(2 \mathrm{H}, \mathrm{d}, J=9.0 \mathrm{~Hz}, \mathrm{Ar}-\mathrm{H}^{3,5}\right), 7.72\left(2 \mathrm{H}, \mathrm{d}, J=9.0 \mathrm{~Hz}, \mathrm{Ar}-\mathrm{H}^{2,6}\right), 7.83(1 \mathrm{H}, \mathrm{s}, \mathrm{Ar}-\mathrm{CH}), 7.93(1 \mathrm{H}, \mathrm{d}$, $J=7.8 \mathrm{~Hz}, 7$-aza-2-oxindole- $\left.\mathrm{H}^{4}\right), 8.46\left(1 \mathrm{H}, \mathrm{d}, J=8.4 \mathrm{~Hz}, 7\right.$-aza-2-oxindole- $\left.\mathrm{H}^{6}\right) .{ }^{13} \mathrm{C}-\mathrm{NMR}\left(600 \mathrm{MHz}, \mathrm{DMSO}-d_{6}\right) \delta(\mathrm{ppm})$ : $168.74,160.09,156.94,154.74,147.84,138.16,134.87,133.52,132.10,129.20,126.54,124.04,122.37,118.07,117.47$, 115.30, 68.63. ESI-MS $m / z: 279.0(\mathrm{M}+1)^{+}$.

(Z)-3-(2,4,6-trimethoxybenzylidene)-1 $\boldsymbol{H}$-pyrrolo[2,3-b]pyridin-2(3H)-one (6c): Yellow powder, 77.2\% yield, mp: $176.7^{\circ} \mathrm{C}-178.1^{\circ} \mathrm{C} .{ }^{1} \mathrm{H}-\mathrm{NMR}\left(600 \mathrm{MHz}, \mathrm{DMSO}-d_{6}\right) \delta(\mathrm{ppm}): 3.79\left(9 \mathrm{H}, \mathrm{s}, \mathrm{O}-\mathrm{CH}_{3} \times 3\right), 6.19\left(2 \mathrm{H}, \mathrm{s}, \mathrm{Ar}-\mathrm{H}^{3,5}\right), 6.81-6.83$ $\left(1 \mathrm{H}, \mathrm{m}, 7\right.$-aza-2-oxindole- $\left.\mathrm{H}^{5}\right), 7.15\left(1 \mathrm{H}, \mathrm{d}, J=6.0 \mathrm{~Hz}, 7\right.$-aza-2-oxindole- $\left.\mathrm{H}^{4}\right), 7.88(1 \mathrm{H}, \mathrm{s}, \mathrm{Ar}-\mathrm{CH}), 8.04(1 \mathrm{H}, \mathrm{d}, J=6.0 \mathrm{~Hz}$, 7-aza-2-oxindole-H $\left.{ }^{6}\right) .{ }^{13} \mathrm{C}-\mathrm{NMR}\left(600 \mathrm{MHz}, \mathrm{DMSO}-d_{6}\right) \delta(\mathrm{ppm}): 175.92,166.24,165.93,163.64 \times 2,159.23,143.65,130.65$, $127.75,116.04,108.12,105.04,91.03 \times 2,55.86 \times 3$. ESI-MS $m / z: 313.2(\mathrm{M}+1)^{+}$.

(Z)-3-(2-chlorobenzylidene)-1 H-pyrrolo[2,3-b]pyridin-2(3H)-one (6d): Yellow powder, $55.2 \%$ yield, $\mathrm{mp}: 198.5^{\circ} \mathrm{C}-199.5^{\circ} \mathrm{C}$. ${ }^{1} \mathrm{H}-\mathrm{NMR}\left(600 \mathrm{MHz}, \mathrm{DMSO}-d_{6}\right) \delta(\mathrm{ppm}): 6.79-6.81\left(1 \mathrm{H}, \mathrm{m}, 7\right.$-aza-2-oxindole- $\left.\mathrm{H}^{5}\right), 7.35-7.43\left(3 \mathrm{H}, \mathrm{m}, \mathrm{Ar}-\mathrm{H}^{4-6}\right), 7.53(1 \mathrm{H}, \mathrm{d}$, $\left.J=7.8 \mathrm{~Hz}, \mathrm{Ar}-\mathrm{H}^{3}\right), 7.55\left(1 \mathrm{H}, \mathrm{d}, J=6.0 \mathrm{~Hz}, 7\right.$-aza-2-oxindole- $\left.\mathrm{H}^{4}\right), 7.66\left(1 \mathrm{H}, \mathrm{d}, J=6.0 \mathrm{~Hz}, 7\right.$-aza-2-oxindole- $\left.\mathrm{H}^{6}\right), 7.99(1 \mathrm{H}, \mathrm{s}$, Ar-CH). ${ }^{13} \mathrm{C}-\mathrm{NMR}\left(600 \mathrm{MHz}\right.$, DMSO- $\left.d_{6}\right) \delta$ (ppm): 167.92, 157.45, 148.91, 133.57, 133.30, 132.59, 131.90, 130.59, 130.17, $129.92,128.29,127.81,117.74,115.16$. ESI-MS m/z: $256.9(\mathrm{M}+1)^{+}$.

(Z)-3-[(1-methyl-1H-indol-3-yl)methylene]-1 $H$-pyrrolo[2,3-b]pyridin-2(3H)-one (6e): Yellow powder, 50.1\% yield, mp: 296. $4^{\circ} \mathrm{C}-297.5^{\circ} \mathrm{C}$. ESI-MS m/z: $276.0(\mathrm{M}+1)^{+}\left(\right.$see Wood et al $\left.{ }^{1}\right)$.

(Z)-3-[4-(piperazin-1-yl)benzylidene]-1 $\boldsymbol{H}$-pyrrolo[2,3-b]pyridin-2(3H)-one (6f): Orange powder, $74.3 \%$ yield, mp: $72.3^{\circ} \mathrm{C}-74.1^{\circ} \mathrm{C} .{ }^{1} \mathrm{H}-\mathrm{NMR}\left(600 \mathrm{MHz}, \mathrm{DMSO}-d_{6}\right) \delta(\mathrm{ppm}): 2.82\left(4 \mathrm{H}, \mathrm{t}, J=5.4 \mathrm{~Hz}, \mathrm{~N}-\mathrm{CH}_{2} \times 2\right), 3.26(4 \mathrm{H}, \mathrm{t}$, $\left.J=5.4 \mathrm{~Hz},-\mathrm{N}-\mathrm{CH}_{2} \times 2\right), 6.91-6.93\left(1 \mathrm{H}, \mathrm{m}, 7\right.$-aza-2-oxindole- $\left.\mathrm{H}^{5}\right), 7.04\left(2 \mathrm{H}, \mathrm{d}, J=9.0 \mathrm{~Hz}, \mathrm{Ar}-\mathrm{H}^{3,5}\right), 7.64(2 \mathrm{H}, \mathrm{d}, J=9.0 \mathrm{~Hz}$, Ar- $\left.\mathrm{H}^{2,6}\right), 7.72(1 \mathrm{H}, \mathrm{s}, \mathrm{Ar}-\mathrm{CH}), 7.95\left(1 \mathrm{H}, \mathrm{d}, J=4.8 \mathrm{~Hz}, 7\right.$-aza-2-oxindole- $\left.\mathrm{H}^{4}\right), 8.05$ (1H, d, $J=4.8 \mathrm{~Hz}, 7$-aza-2-oxindole- $\left.\mathrm{H}^{6}\right)$. ${ }^{13} \mathrm{C}-\mathrm{NMR}\left(600 \mathrm{MHz}\right.$, DMSO- $\left.d_{6}\right) \delta(\mathrm{ppm}): 169.11,156.48,152.76,147.07,138.95,135.06,132.33 \times 2,128.75,121.34$, $117.35,113.94 \times 2,113.22,63.01 \times 2,47.94 \times 2$. ESI-MS m/z: $306.8(\mathrm{M}+1)^{+}$.

(Z)-3-[4-(4-methylpiperazin-1-yl)benzylidene]-1 $\boldsymbol{H}$-pyrrolo[2,3-b]pyridin-2(3H)-one (6g): Orange oil, 53.7\% yield. ${ }^{1} \mathrm{H}-\mathrm{NMR}\left(600 \mathrm{MHz}, \mathrm{DMSO}-d_{6}\right) \delta(\mathrm{ppm}): 2.24\left(3 \mathrm{H}, \mathrm{s}, \mathrm{N}-\mathrm{CH}_{3}\right), 2.46\left(4 \mathrm{H}, \mathrm{t}, J=5.4 \mathrm{~Hz}, \mathrm{C}-\mathrm{N}-\mathrm{CH}_{2} \times 2\right), 3.38$ $\left(4 \mathrm{H}, \mathrm{t}, J=5.4 \mathrm{~Hz},-\mathrm{N}-\mathrm{CH}_{2} \times 2\right), 6.91-6.93\left(1 \mathrm{H}, \mathrm{m}, 7\right.$-aza-2-oxindole- $\left.\mathrm{H}^{5}\right), 7.06\left(2 \mathrm{H}, \mathrm{d}, J=9.0 \mathrm{~Hz}, \mathrm{Ar}-\mathrm{H}^{3,5}\right), 7.65(2 \mathrm{H}, \mathrm{d}$, $\left.J=9.0 \mathrm{~Hz}, \mathrm{Ar}-\mathrm{H}^{2,6}\right), 7.72(1 \mathrm{H}, \mathrm{s}, \mathrm{Ar}-\mathrm{CH}), 7.95\left(1 \mathrm{H}, \mathrm{d}, J=7.2 \mathrm{~Hz}, 7\right.$-aza-2-oxindole- $\left.\mathrm{H}^{4}\right), 8.01(1 \mathrm{H}, \mathrm{d}, J=7.2 \mathrm{~Hz}, 7$-aza-2oxindole- $\left.\mathrm{H}^{6}\right) .{ }^{13} \mathrm{C}-\mathrm{NMR}\left(600 \mathrm{MHz}, \mathrm{DMSO}-d_{6}\right): \delta(\mathrm{ppm}): 169.09,156.48,152.27,147.13,138.90,135.02,132.28 \times 2$, $123.05,121.55,117.36,116.19,114.13 \times 2,54.49 \times 2,46.77 \times 2,45.85$. ESI-MS $m / z: 321.01(\mathrm{M}+1)^{+}$.

(Z)-3-(4-morpholinobenzylidene)-1 $\boldsymbol{H}$-pyrrolo[2,3-b]pyridin-2(3H)-one (6h): Orange powder, 77.1\% yield, mp: $57.7^{\circ} \mathrm{C}-58.5^{\circ} \mathrm{C} .{ }^{1} \mathrm{H}-\mathrm{NMR}\left(600 \mathrm{MHz}, \mathrm{DMSO}-d_{6}\right) \delta(\mathrm{ppm}): 3.32\left(4 \mathrm{H}, \mathrm{t}, J=5.4 \mathrm{~Hz}, \mathrm{O}-\mathrm{CH}_{2} \times 2\right), 3.71(4 \mathrm{H}, \mathrm{t}$, $\left.J=5.4 \mathrm{~Hz},-\mathrm{N}-\mathrm{CH}_{2} \times 2\right), 6.91-6.94\left(1 \mathrm{H}, \mathrm{m}, 7\right.$-aza-2-oxindole- $\left.\mathrm{H}^{5}\right), 7.03\left(2 \mathrm{H}, \mathrm{d}, J=9.0 \mathrm{~Hz}, \mathrm{Ar}-\mathrm{H}^{3,5}\right), 7.64(1 \mathrm{H}, \mathrm{s}, \mathrm{Ar}-\mathrm{CH})$, $7.72\left(2 \mathrm{H}, \mathrm{d}, J=9.0 \mathrm{~Hz}, \mathrm{Ar}-\mathrm{H}^{2,6}\right), 8.00\left(1 \mathrm{H}, \mathrm{d}, J=6.0 \mathrm{~Hz}, 7\right.$-aza-2-oxindole- $\left.\mathrm{H}^{4}\right), 8.04$ (1H, d, $J=6.0 \mathrm{~Hz}, 7$-aza-2-oxindole- $\left.\mathrm{H}^{6}\right)$. ${ }^{13} \mathrm{C}-\mathrm{NMR}\left(600 \mathrm{MHz}, \mathrm{DMSO}-d_{6}\right) \delta(\mathrm{ppm}): 169.02,156.59,155.15,147.24,138.80,134.90,131.62 \times 2,128.81,126.93$, $121.91,117.35,113.42 \times 2,66.03 \times 2,46.82 \times 2$. ESI-MS $m / z: 307.91(\mathrm{M}+1)^{+}$.

(Z)-4-\{4-[(2-0xo-1 H-pyrrolo[2,3-b]pyridin-3(2H)-ylidene)methyl]phenyl\}piperazine-1-carbaldehyde (6i): Yellow powder, $32.3 \%$ yield, mp: $105.3^{\circ} \mathrm{C}-106.6^{\circ} \mathrm{C} .{ }^{1} \mathrm{H}-\mathrm{NMR}\left(600 \mathrm{MHz}\right.$, DMSO- $\left.d_{6}\right) \delta(\mathrm{ppm}): 3.52\left(8 \mathrm{H}, \mathrm{t}, J=5.4 \mathrm{~Hz},-\mathrm{N}-\mathrm{CH}_{2} \times 4\right)$, 6.91-6.94 (1H, m, 7-aza-2-oxindole- $\left.\mathrm{H}^{5}\right), 7.11\left(2 \mathrm{H}, \mathrm{d}, J=9.0 \mathrm{~Hz}, \mathrm{Ar}-\mathrm{H}^{3,5}\right), 7.67\left(2 \mathrm{H}, \mathrm{d}, J=9.0 \mathrm{~Hz}, \mathrm{Ar}-\mathrm{H}^{2,6}\right), 7.74(1 \mathrm{H}, \mathrm{s}$, Ar-CH), $7.95\left(1 \mathrm{H}, \mathrm{d}, J=7.2 \mathrm{~Hz}, 7\right.$-aza-2-oxindole- $\left.\mathrm{H}^{4}\right), 8.00\left(1 \mathrm{H}, \mathrm{d}, J=7.2 \mathrm{~Hz}\right.$, 7-aza-2-oxindole- $\left.\mathrm{H}^{6}\right), 8.10(1 \mathrm{H}, \mathrm{s},-\mathrm{N}-\mathrm{CHO})$. 
${ }^{13} \mathrm{C}-\mathrm{NMR}\left(600 \mathrm{MHz}, \mathrm{DMSO}-d_{6}\right) \delta(\mathrm{ppm}): 169.01,161.44 \times 3,147.27,138.72,134.96,132.24 \times 2,128.84,123.64,117.36$, $114.77 \times 2,113.97,45.64 \times 2,44.53 \times 2$. ESI-MS $m / z: 334.98(\mathrm{M}+1)^{+}$.

(Z)-3-[4-(4-acryloylpiperazin-1-yl)benzylidene]-1H-pyrrolo[2,3-b]pyridin-2(3H)-one (6j): Orange oil, 31.9\% yield. ${ }^{1} \mathrm{H}-\mathrm{NMR}\left(600 \mathrm{MHz}\right.$, DMSO- $\left.d_{6}\right) \delta(\mathrm{ppm}): 3.75\left(8 \mathrm{H}, \mathrm{t}, J=6.6 \mathrm{~Hz},-\mathrm{N}-\mathrm{CH}_{2} \times 4\right), 5.72\left(1 \mathrm{H}, \mathrm{dd}, J_{1}=1.8 \mathrm{~Hz}, J_{2}=10.8 \mathrm{~Hz}\right.$, $\mathrm{CO}-\mathrm{C}=\mathrm{CH}), 6.15\left(1 \mathrm{H}, \mathrm{dd}, J_{1}=1.8 \mathrm{~Hz}, J_{2}=14.4 \mathrm{~Hz}, \mathrm{CO}-\mathrm{C}=\mathrm{CH}\right), 6.81-6.88(1 \mathrm{H}, \mathrm{m}, \mathrm{CO}-\mathrm{CH}=\mathrm{C}), 6.92-6.94(1 \mathrm{H}, \mathrm{m}, 7$-aza2-oxindole- $\left.\mathrm{H}^{5}\right), 7.04\left(2 \mathrm{H}, \mathrm{d}, J=7.8 \mathrm{~Hz}, \mathrm{Ar}-\mathrm{H}^{3,5}\right), 7.08\left(1 \mathrm{H}, \mathrm{d}, J=9.0 \mathrm{~Hz}, 7\right.$-aza-2-oxindole- $\left.\mathrm{H}^{4}\right), 7.66\left(2 \mathrm{H}, \mathrm{d}, J=7.8 \mathrm{~Hz}, \mathrm{Ar}-\mathrm{H}^{2,6}\right)$, $7.73(1 \mathrm{H}, \mathrm{s}, \mathrm{Ar}-\mathrm{CH}), 8.06\left(1 \mathrm{H}, \mathrm{d}, J=7.8 \mathrm{~Hz}, 7\right.$-aza-2-oxindole- $\left.\mathrm{H}^{6}\right) .{ }^{13} \mathrm{C}-\mathrm{NMR}\left(600 \mathrm{MHz}\right.$, DMSO- $\left.d_{6}\right) \delta(\mathrm{ppm}): 171.77,167.20$, $164.58,151.88,147.22,138.80,134.98,132.28 \times 2,131.74,128.87,128.35,127.80,126.32,117.36,114.32 \times 2,45.88 \times 2$, $37.39 \times 2$. ESI-MS $m / z: 360.9(\mathrm{M}+1)^{+}$.

(Z)-3-\{4-[4-(3-chloropropanoyl)piperazin-1-yl]benzylidene\}-1 $H$-pyrrolo[2,3-b]pyridin-2(3H)-one (6k): Orange powder, $34.4 \%$ yield, mp: $45.4^{\circ} \mathrm{C}-46.9^{\circ} \mathrm{C} .{ }^{1} \mathrm{H}-\mathrm{NMR}\left(600 \mathrm{MHz}, \mathrm{DMSO}-d_{6}\right) \delta(\mathrm{ppm}): 3.05\left(2 \mathrm{H}, \mathrm{t}, J=7.2 \mathrm{~Hz}, \mathrm{OC}-\mathrm{CH}_{2}\right), 3.39(4 \mathrm{H}$, $\left.\mathrm{t}, J=6.0 \mathrm{~Hz}, \mathrm{OC}-\mathrm{N}-\mathrm{CH}_{2} \times 2\right), 3.62\left(4 \mathrm{H}, \mathrm{t}, J=6.0 \mathrm{~Hz},-\mathrm{N}-\mathrm{CH}_{2} \times 2\right), 3.82\left(2 \mathrm{H}, \mathrm{t}, J=7.2 \mathrm{~Hz},-\mathrm{CH}_{2}-\mathrm{Cl}\right), 6.91-6.93(1 \mathrm{H}, \mathrm{m}$, 7-aza-2-oxindole- $\left.\mathrm{H}^{5}\right), 7.07\left(2 \mathrm{H}, \mathrm{d}, J=9.0 \mathrm{~Hz}, \mathrm{Ar}-\mathrm{H}^{3,5}\right), 7.66\left(2 \mathrm{H}, \mathrm{d}, J=9.0 \mathrm{~Hz}, \mathrm{Ar}-\mathrm{H}^{2,6}\right), 7.73(1 \mathrm{H}, \mathrm{s}, \mathrm{Ar}-\mathrm{CH}), 7.95(1 \mathrm{H}, \mathrm{d}$, $J=7.8 \mathrm{~Hz}, 7$-aza-2-oxindole- $\left.\mathrm{H}^{4}\right), 8.00\left(1 \mathrm{H}, \mathrm{d}, J=7.8 \mathrm{~Hz}, 7\right.$-aza-2-oxindole- $\left.\mathrm{H}^{6}\right) .{ }^{13} \mathrm{C}-\mathrm{NMR}\left(600 \mathrm{MHz}, \mathrm{DMSO}-d_{6}\right) \delta(\mathrm{ppm})$ : $169.04,167.28,156.56,154.24,139.74,138.80,134.99,132.28 \times 2,128.35,127.79,117.36,114.31 \times 2,113.52,45.66 \times 4$, 40.78, 35.45. ESI-MS m/z: $397.33(\mathrm{M}+1)^{+}$.

(Z)-3-[4-(allyloxy)-2-hydroxybenzylidene]indolin-2-one (7a): Yellow oil, 37.2\% yield. ${ }^{1} \mathrm{H}-\mathrm{NMR}$ (600 MHz, DMSO- $d_{6}$ ) $\delta(\mathrm{ppm}): 4.59\left(2 \mathrm{H}, \mathrm{d}, J=4.8 \mathrm{~Hz}, \mathrm{O}-\mathrm{CH}_{2}\right), 5.29\left(1 \mathrm{H}, \mathrm{dd}, J_{1}=1.8 \mathrm{~Hz}, J_{2}=10.2 \mathrm{~Hz},-\mathrm{C}=\mathrm{CH}_{2}\right), 5.42\left(1 \mathrm{H}, \mathrm{dd}, J_{1}=1.8 \mathrm{~Hz}\right.$, $\left.J_{2}=16.2 \mathrm{~Hz},-\mathrm{C}=\mathrm{CH}_{2}\right), 6.02-6.08(1 \mathrm{H}, \mathrm{m},-\mathrm{CH}=\mathrm{C}), 6.53\left(1 \mathrm{H}, \mathrm{s}, \mathrm{Ar}-\mathrm{H}^{3}\right), 6.57\left(1 \mathrm{H}, \mathrm{d}, J=8.4 \mathrm{~Hz}, \mathrm{Ar}-\mathrm{H}^{5}\right), 6.85(1 \mathrm{H}, \mathrm{d}$, $J=7.8 \mathrm{~Hz}$, indolin-2-one- $\left.\mathrm{H}^{7}\right), 7.14-7.20\left(2 \mathrm{H}, \mathrm{m}\right.$, indolin-2-one- $\left.\mathrm{H}^{5,6}\right), 7.62\left(1 \mathrm{H}, \mathrm{d}, J=8.4 \mathrm{~Hz}, \mathrm{Ar}-\mathrm{H}^{6}\right), 7.66(1 \mathrm{H}, \mathrm{s}, \mathrm{Ar}-\mathrm{CH})$, $8.88\left(1 \mathrm{H}, \mathrm{d}, J=8.4 \mathrm{~Hz}\right.$, indolin-2-one- $\left.\mathrm{H}^{4}\right) .{ }^{13} \mathrm{C}-\mathrm{NMR}\left(600 \mathrm{MHz}, \mathrm{DMSO}-d_{6}\right) \delta(\mathrm{ppm}): 169.31,161.47,158.54,142.52$, $139.12,133.62,132.54,130.86,129.35,124.55,122.19,121.11,117.94,114.55,110.04,106.10,102.15,68.50$. ESI-MS $\mathrm{m} / \mathrm{z}: 292.7(\mathrm{M}-1)^{-}$.

(Z)-3-[4-(allyloxy)benzylidene]indolin-2-one (7b): Yellow powder, $60.1 \%$ yield, mp: $165.7^{\circ} \mathrm{C}-166.3^{\circ} \mathrm{C}$. ESI-MS $\mathrm{m} / \mathrm{z}$ : $278.3(\mathrm{M}+1)^{+}\left(\right.$see $C h e n$ et $\left.\mathrm{al}^{2}\right)$.

(Z)-3-(2,4,6-trimethoxybenzylidene)indolin-2-one (7c): Yellow powder, $83.1 \%$ yield, mp: $178.1^{\circ}-179.0^{\circ} \mathrm{C}$. ESI-MS $\mathrm{m} / \mathrm{z}$ : $311.9(\mathrm{M}+1)^{+}\left(\right.$see Yang et $\left.\mathrm{al}^{3}\right)$.

(Z)-3-[2-(trifluoromethyl)benzylidene]indolin-2-one (7d): Yellow powder, $73 \%$ yield, mp: $149.5^{\circ} \mathrm{C}-151.0^{\circ} \mathrm{C}$. ESI-MS $m / z: 290.2(\mathrm{M}+1)^{+}\left(\right.$see Zhang et $\left.\mathrm{a}^{4}\right)$.

(Z)-3-[4-(piperazin-1-yl)benzylidene]indolin-2-one (7e): Orange powder, $80.4 \%$ yield, mp: $225.4^{\circ} \mathrm{C}-226.9^{\circ} \mathrm{C} .{ }^{1} \mathrm{H}-\mathrm{NMR}$ $\left(600 \mathrm{MHz}, \mathrm{DMSO}-d_{6}\right) \delta(\mathrm{ppm}): 2.82\left(4 \mathrm{H}, \mathrm{t}, J=5.4 \mathrm{~Hz}, \mathrm{~N}-\mathrm{CH}_{2} \times 2\right), 3.25\left(4 \mathrm{H}, \mathrm{t}, J=5.4 \mathrm{~Hz},-\mathrm{N}-\mathrm{CH}_{2} \times 2\right), 6.80(2 \mathrm{H}, \mathrm{d}, J=7.8$ $\left.\mathrm{Hz}, \mathrm{Ar}-\mathrm{H}^{3,5}\right), 7.02\left(1 \mathrm{H}, \mathrm{d}, J=8.4 \mathrm{~Hz}\right.$, indole-2-one- $\left.\mathrm{H}^{7}\right), 7.11-7.14\left(1 \mathrm{H}, \mathrm{m}\right.$, indole-2-one- $\left.\mathrm{H}^{5}\right), 7.17-7.20(1 \mathrm{H}, \mathrm{m}$, indole2-one- $\left.\mathrm{H}^{6}\right), 7.52(1 \mathrm{H}, \mathrm{s}, \mathrm{Ar}-\mathrm{CH}), 7.76\left(2 \mathrm{H}, \mathrm{d}, J=7.8 \mathrm{~Hz}, \mathrm{Ar}-\mathrm{H}^{2,6}\right), 8.42\left(1 \mathrm{H}, \mathrm{d}, J=8.4 \mathrm{~Hz}\right.$, indole-2-one- $\left.\mathrm{H}^{4}\right) .{ }^{13} \mathrm{C}-\mathrm{NMR}(600 \mathrm{MHz}$, DMSO- $\left.d_{6}\right) \delta(\mathrm{ppm}): 169.47,142.49,139.94,134.68,131.84 \times 2,129.24,127.56,126.10,123.99,123.40,121.11,113.97 \times 2$, $113.30,48.17 \times 2,45.65 \times 2$. ESI-MS $m / z: 306.1(\mathrm{M}+1)^{+}$.

(Z)-3-[4-(4-methylpiperazin-1-yl)benzylidene]indolin-2-one (7f): Orange powder, 82.3\% yield, mp: $191.6^{\circ} \mathrm{C}-193.0^{\circ} \mathrm{C}$. ESI-MS $m / z: 320.19(\mathrm{M}+1)^{+}\left(\right.$see Furuta et $\left.\mathrm{al}^{5}\right)$.

(Z)-3-(4-morpholinobenzylidene)indolin-2-one (7g): Orange powder, $85.3 \%$ yield, mp: $239.3^{\circ} \mathrm{C}-240.1{ }^{\circ} \mathrm{C}$. ESI-MS $\mathrm{m} / \mathrm{z}$ : $307.09(\mathrm{M}+1)^{+}\left(\right.$see Vieth et $\left.\mathrm{al}^{6}\right)$. 
(Z)-4-\{4-[(2-oxoindolin-3-ylidene)methyl]phenyl)\}piperazine-1-carbaldehyde (7h): Yellow powder, 45.7\% yield, mp: $204.7^{\circ} \mathrm{C}-205.6^{\circ} \mathrm{C}$. ESI-MS $m / z: 334.09(\mathrm{M}+1)^{+}\left(\right.$see Ravindranathan et $\left.\mathrm{al}^{7}\right)$.

(Z)-3-[4-(4-acryloylpiperazin-1-yl)benzylidene]indolin-2-one (7i): Orange powder, $27.5 \%$ yield, $\mathrm{mp}: 135.6^{\circ} \mathrm{C}-136.9^{\circ} \mathrm{C}$. ${ }^{1} \mathrm{H}-\mathrm{NMR}\left(600 \mathrm{MHz}, \mathrm{DMSO}-d_{6}\right) \delta(\mathrm{ppm}): 3.69\left(8 \mathrm{H}, \mathrm{t}, J=5.4 \mathrm{~Hz},-\mathrm{N}-\mathrm{CH}_{2} \times 4\right), 5.71\left(1 \mathrm{H}, \mathrm{dd}, J_{1}=1.8 \mathrm{~Hz}, J_{2}=10.8 \mathrm{~Hz}\right.$, $\mathrm{CO}-\mathrm{C}=\mathrm{CH}), 6.15\left(1 \mathrm{H}, \mathrm{dd}, J_{1}=1.8 \mathrm{~Hz}, J_{2}=16.8 \mathrm{~Hz}, \mathrm{CO}-\mathrm{C}=\mathrm{CH}\right), 6.80-6.84(1 \mathrm{H}, \mathrm{m}, \mathrm{CO}-\mathrm{CH}=\mathrm{C}), 6.88(2 \mathrm{H}, \mathrm{d}, J=7.8 \mathrm{~Hz}$, Ar- $\left.\mathrm{H}^{3,5}\right), 7.04\left(1 \mathrm{H}, \mathrm{d}, J=9.0 \mathrm{~Hz}\right.$, indole-2-one- $\left.\mathrm{H}^{7}\right), 7.12-7.15\left(1 \mathrm{H}, \mathrm{m}\right.$, indole-2-one- $\left.\mathrm{H}^{5}\right), 7.18-7.21\left(1 \mathrm{H}, \mathrm{m}\right.$, indole-2-one- $\left.\mathrm{H}^{6}\right)$, $7.53(1 \mathrm{H}, \mathrm{s}, \mathrm{Ar}-\mathrm{CH}), 7.74\left(2 \mathrm{H}, \mathrm{d}, J=7.8 \mathrm{~Hz}, \mathrm{Ar}-\mathrm{H}^{2,6}\right), 8.44\left(1 \mathrm{H}, \mathrm{d}, J=9.0 \mathrm{~Hz}\right.$, indole-2-one- $\left.\mathrm{H}^{4}\right) .{ }^{13} \mathrm{C}-\mathrm{NMR}\left(600 \mathrm{MHz}, \mathrm{DMSO}-d_{6}\right)$ $\delta$ (ppm): $169.44,164.57,151.54,142.56,136.84,134.63,131.79 \times 2,129.38,128.29,127.79,123.99,122.11,121.74,121.15$, $114.37 \times 2,113.66,47.43 \times 2,44.75 \times 2$. ESI-MS $m / z: 360.41(\mathrm{M}+1)^{+}$. HRMS (ESI) calculated for $\mathrm{C}_{22} \mathrm{H}_{21} \mathrm{~N}_{3} \mathrm{O}_{2}(\mathrm{MH}+)$, 360.1707; found, 360.1711 .

(Z)-3-\{4-[4-(3-chloropropanoyl)piperazin-1-yl]benzylidene\}indolin-2-one (7j): Orange powder, 31.8\% yield, mp: $77.3^{\circ} \mathrm{C}-78.5^{\circ} \mathrm{C} .{ }^{1} \mathrm{H}-\mathrm{NMR}\left(600 \mathrm{MHz}, \mathrm{DMSO}-d_{6}\right) \delta(\mathrm{ppm}): 2.88\left(2 \mathrm{H}, \mathrm{t}, J=6.6 \mathrm{~Hz}, \mathrm{CO}-\mathrm{CH}_{2}\right), 3.38(4 \mathrm{H}, \mathrm{t}, J=5.4 \mathrm{~Hz}$, $\left.\mathrm{CO}-\mathrm{N}-\mathrm{CH}_{2} \times 2\right), 3.68\left(4 \mathrm{H}, \mathrm{t}, J=5.4 \mathrm{~Hz},-\mathrm{N}-\mathrm{CH}_{2} \times 2\right), 3.88\left(2 \mathrm{H}, \mathrm{t}, J=6.6 \mathrm{~Hz},-\mathrm{CH}_{2}-\mathrm{Cl}\right), 6.87\left(2 \mathrm{H}, \mathrm{d}, J=7.8 \mathrm{~Hz}, \mathrm{Ar}-\mathrm{H}^{3,5}\right)$, $6.96\left(1 \mathrm{H}, \mathrm{d}, J=9.0 \mathrm{~Hz}\right.$, indole-2-one- $\left.\mathrm{H}^{7}\right), 7.01-7.04\left(1 \mathrm{H}, \mathrm{m}\right.$, indole-2-one- $\left.\mathrm{H}^{5}\right), 7.18-7.21\left(1 \mathrm{H}, \mathrm{m}\right.$, indole-2-one- $\left.\mathrm{H}^{6}\right), 7.75$ $(1 \mathrm{H}, \mathrm{s}, \mathrm{Ar}-\mathrm{CH}), 7.81\left(2 \mathrm{H}, \mathrm{d}, J=7.8 \mathrm{~Hz}, \mathrm{Ar}-\mathrm{H}^{2,6}\right), 8.34\left(1 \mathrm{H}, \mathrm{d}, J=9.0 \mathrm{~Hz}\right.$, indole-2-one- $\left.\mathrm{H}^{4}\right) .{ }^{13} \mathrm{C}-\mathrm{NMR}\left(600 \mathrm{MHz}, \mathrm{DMSO}-d_{6}\right)$ $\delta(\mathrm{ppm}): 169.40,168.14,142.57,136.81,134.63,131.79 \times 2,129.37,126.00,124.00,121.74,121.13,120.92,114.38 \times 2$, 110.12, 47.20, 46.90, 44.48, 44.42, 40.79, 35.46. ESI-MS m/z: $395.95(\mathrm{M}+1)^{+}$.

(Z)-3-[4-(4-benzoylpiperazin-1-yl)benzylidene]indolin-2-one (7k): Orange powder, $40.3 \%$ yield, mp: $204.2^{\circ} \mathrm{C}-205.3^{\circ} \mathrm{C}$. ${ }^{1} \mathrm{H}-\mathrm{NMR}\left(600 \mathrm{MHz}, \mathrm{DMSO}-d_{6}\right) \delta(\mathrm{ppm}): 3.47\left(4 \mathrm{H}, \mathrm{t}, J=5.4 \mathrm{~Hz},-\mathrm{N}-\mathrm{CH}_{2} \times 2\right), 3.77\left(4 \mathrm{H}, \mathrm{t}, J=5.4 \mathrm{~Hz}, \mathrm{CO}-\mathrm{N}-\mathrm{CH}_{2} \times 2\right)$, $6.79\left(2 \mathrm{H}, \mathrm{d}, J=7.8 \mathrm{~Hz}, \mathrm{Ar}-\mathrm{H}^{3,5}\right), 7.06\left(1 \mathrm{H}, \mathrm{d}, J=9.0 \mathrm{~Hz}\right.$, indole-2-one- $\left.\mathrm{H}^{7}\right), 7.12-7.14\left(1 \mathrm{H}, \mathrm{m}\right.$, indole-2-one- $\left.\mathrm{H}^{5}\right), 7.18-7.20$ $\left(1 \mathrm{H}, \mathrm{m}\right.$, indole-2-one- $\left.\mathrm{H}^{6}\right), 7.45-7.47\left(3 \mathrm{H}, \mathrm{m}, \mathrm{CO}-\mathrm{Ar}-\mathrm{H}^{3-5}\right), 7.53(1 \mathrm{H}, \mathrm{s}, \mathrm{Ar}-\mathrm{CH}), 7.74\left(2 \mathrm{H}, \mathrm{d}, J=7.8 \mathrm{~Hz}, \mathrm{Ar}-\mathrm{H}^{2,6}\right), 7.62-7.66$ $\left(2 \mathrm{H}, \mathrm{m}, \mathrm{CO}-\mathrm{Ar}-\mathrm{H}^{2,6}\right), 8.44\left(1 \mathrm{H}, \mathrm{d}, J=9.0 \mathrm{~Hz}\right.$, indole-2-one- $\left.\mathrm{H}^{4}\right) .{ }^{13} \mathrm{C}-\mathrm{NMR}\left(600 \mathrm{MHz}, \mathrm{DMSO}-d_{6}\right) \delta(\mathrm{ppm}): 169.32,151.59$, $142.58,136.79,135.99,131.78,129.86,129.40,128.69 \times 2,127.24 \times 3,125.99,124.11,124.07,122.09,121.73,121.13$, $114.52 \times 2,113.80,47.63 \times 2,44.55 \times 2$. ESI-MS $m / z: 409.9(\mathrm{M}+1)^{+}$.

(Z)-5-chloro-3-[(2-mercapto-1 H-benzo[d]imidazol-6-yl)imino]indolin-2-one (8a): Orange powder, 67.3\% yield, $\mathrm{mp}:>300^{\circ} \mathrm{C} .{ }^{1} \mathrm{H}-\mathrm{NMR}\left(600 \mathrm{MHz}, \mathrm{DMSO}-d_{6}\right) \delta(\mathrm{ppm}): 6.87\left(1 \mathrm{H}, \mathrm{d}, J=10.2 \mathrm{~Hz}\right.$, benzoimidazol- $\left.\mathrm{H}^{5}\right), 6.98(1 \mathrm{H}$, d, $J=10.2 \mathrm{~Hz}$, indolin-2-one- $\left.\mathrm{H}^{6}\right), 7.04\left(1 \mathrm{H}\right.$, s, benzoimidazol- $\left.\mathrm{H}^{7}\right), 7.09\left(1 \mathrm{H}, \mathrm{d}, J=10.2 \mathrm{~Hz}\right.$, benzoimidazol- $\left.\mathrm{H}^{4}\right), 7.46(1 \mathrm{H}, \mathrm{d}$, $J=10.2 \mathrm{~Hz}$, indolin-2-one- $\left.\mathrm{H}^{7}\right), 7.55\left(1 \mathrm{H}\right.$, s, indolin-2-one- $\left.\mathrm{H}^{4}\right) .{ }^{13} \mathrm{C}-\mathrm{NMR}\left(600 \mathrm{MHz}, \mathrm{DMSO}-d_{6}\right) \delta(\mathrm{ppm}): 169.03,163.53$, $154.28,145.96,145.04,133.85,133.35,130.58,125.40,124.58,122.24,117.12,113.09,110.47,101.84$. ESI-MS $m / z$ : $329.78(\mathrm{M}+1)^{+}$.

(Z)-1-\{2-[2-(5-chloro-2-oxoindolin-3-ylidene)hydrazinyl]-2-oxoethyl\}pyridin-1-iumchloride (8b): Yellow powder, 78.9\% yield, mp: $235.5^{\circ} \mathrm{C}-236.7^{\circ} \mathrm{C} .{ }^{~} \mathrm{H}-\mathrm{NMR}\left(600 \mathrm{MHz}, \mathrm{DMSO}-d_{6}\right) \delta(\mathrm{ppm}): 6.22\left(2 \mathrm{H}, \mathrm{s},-\mathrm{N}-\mathrm{CO}-\mathrm{CH}_{2}-\right), 7.05(1 \mathrm{H}, \mathrm{d}, J=8.4$ $\mathrm{Hz}$, indolin-2-one- $\left.\mathrm{H}^{6}\right), 7.48\left(1 \mathrm{H}, \mathrm{d}, J=8.4 \mathrm{~Hz}\right.$, indolin-2-one- $\left.\mathrm{H}^{7}\right), 7.59\left(1 \mathrm{H}, \mathrm{s}\right.$, indolin-2-one- $\left.\mathrm{H}^{4}\right), 8.27\left(2 \mathrm{H}, \mathrm{m}\right.$, pyridin- $\left.\mathrm{H}^{3,5}\right)$, $8.73\left(1 \mathrm{H}, \mathrm{m}\right.$, pyridin- $\left.\mathrm{H}^{4}\right), 9.11\left(2 \mathrm{H}, \mathrm{d}, J=5.4 \mathrm{~Hz}\right.$, pyridin- $\left.\mathrm{H}^{2,6}\right) .{ }^{13} \mathrm{C}-\mathrm{NMR}\left(600 \mathrm{MHz}, \mathrm{DMSO}-d_{6}\right) \delta(\mathrm{ppm}): 169.04,163.53$, $153.28,146.91,146.72,134.85,133.35,125.41,125.30,123.24,118.22,115.21,113.09,110.50,40.35$. ESI-MS $m / z$ : $315.19(\mathrm{M}-\mathrm{Cl})^{+}$.

(Z)-5-chloro-3-[(2-methyl-1H-indol-5-yl)imino]indolin-2-one (8c): Yellow powder, $79.0 \%$ yield, $\mathrm{mp}: 167.6^{\circ} \mathrm{C}-168.5^{\circ} \mathrm{C}$. ${ }^{1} \mathrm{H}-\mathrm{NMR}\left(600 \mathrm{MHz}, \mathrm{DMSO}-d_{6}\right) \delta(\mathrm{ppm}): 2.36\left(3 \mathrm{H}, \mathrm{s}\right.$, methylindole- $\left.\mathrm{CH}_{3}\right), 6.50\left(1 \mathrm{H}, \mathrm{s}\right.$, methylindole- $\left.\mathrm{H}^{3}\right), 6.74(1 \mathrm{H}, \mathrm{d}$, $J=8.4 \mathrm{~Hz}$, methylindole- $\left.\mathrm{H}^{6}\right), 6.84\left(1 \mathrm{H}, \mathrm{d}, J=7.8 \mathrm{~Hz}\right.$, indolin-2-one- $\left.\mathrm{H}^{6}\right), 6.90\left(1 \mathrm{H}, \mathrm{d}, J=8.4 \mathrm{~Hz}\right.$, methylindole- $\left.\mathrm{H}^{7}\right), 7.13(1 \mathrm{H}, \mathrm{s}$, indolin-2-one- $\left.\mathrm{H}^{4}\right), 7.21\left(1 \mathrm{H}, \mathrm{s}\right.$, methylindole- $\left.\mathrm{H}^{4}\right), 7.33\left(1 \mathrm{H}, \mathrm{d}, J=7.8 \mathrm{~Hz}\right.$, indolin-2-one- $\left.\mathrm{H}^{7}\right) .{ }^{13} \mathrm{C}-\mathrm{NMR}\left(600 \mathrm{MHz}\right.$, DMSO- $\left.d_{6}\right)$ $\delta$ (ppm): $178.34,163.98,152.30,145.49,141.21,135.96,133.70,133.46,129.09,126.05,125.62,124.85,124.17,117.19 \times 2$, 111.39, 13.44. ESI-MS $m / z: 310.45(\mathrm{M}+1)^{+}$. 
(Z)-5-chloro-3-(quinolin-6-ylimino)indolin-2-one (8d): Yellow powder, $79.8 \%$ yield, mp: $197.3^{\circ} \mathrm{C}-198.2^{\circ} \mathrm{C} .{ }^{1} \mathrm{H}-\mathrm{NMR}$ $\left(600 \mathrm{MHz}, \mathrm{DMSO}-d_{6}\right) \delta(\mathrm{ppm}): 7.49-7.51\left(2 \mathrm{H}, \mathrm{m}\right.$, quinolin- $\left.\mathrm{H}^{7,8}\right), 7.56-7.58\left(2 \mathrm{H}, \mathrm{m}\right.$, indolin-2-one- $\mathrm{H}^{6}$, quinolin- $\left.\mathrm{H}^{3}\right), 7.65(1 \mathrm{H}, \mathrm{s}$, indolin-2-one- $\left.\mathrm{H}^{4}\right), 7.94\left(1 \mathrm{H}, \mathrm{d}, J=8.4 \mathrm{~Hz}\right.$, indolin-2-one- $\left.\mathrm{H}^{7}\right), 8.15\left(1 \mathrm{H}, \mathrm{s}\right.$, quinolin- $\left.\mathrm{H}^{5}\right), 8.35\left(1 \mathrm{H}, \mathrm{d}, J=7.8 \mathrm{~Hz}\right.$, quinolin- $\left.\mathrm{H}^{4}\right)$, $8.90\left(1 \mathrm{H}, \mathrm{d}, J=7.8 \mathrm{~Hz}\right.$, quinolin- $\left.\mathrm{H}^{2}\right) .{ }^{13} \mathrm{C}-\mathrm{NMR}\left(600 \mathrm{MHz}\right.$, DMSO- $\left.d_{6}\right) \delta(\mathrm{ppm}): 163.35,154.67,150.26,147.88,146.20,145.99$, $135.99,134.24,130.95,128.28,125.51,124.81,123.93,122.47,117.11 \times 2,113.48$. ESI-MS m/z: $308.37(\mathrm{M}+1)^{+}$.

(Z)-5-chloro-3-[(2,3-dihydro- $\boldsymbol{H}$-inden-5-yl)imino]indolin-2-one $\mathbf{( 8 e )}$ : Orange powder, 83.7\% yield, mp: $269.5^{\circ} \mathrm{C}-270.9^{\circ} \mathrm{C} .{ }^{1} \mathrm{H}-\mathrm{NMR}\left(600 \mathrm{MHz}, \mathrm{DMSO}-d_{6}\right) \delta(\mathrm{ppm}): 2.03-2.09\left(2 \mathrm{H}, \mathrm{m}\right.$, inden- $\left.\mathrm{H}^{4}\right), 2.90(4 \mathrm{H}, \mathrm{t}, J=7.2 \mathrm{~Hz}$, inden- $\left.\mathrm{H}^{3.5}\right), 6.46\left(1 \mathrm{H}, \mathrm{s}\right.$, inden- $\left.\mathrm{H}^{2}\right), 6.76\left(1 \mathrm{H}, \mathrm{d}, J=8.4 \mathrm{~Hz}\right.$, inden- $\left.\mathrm{H}^{7}\right), 6.91\left(1 \mathrm{H}, \mathrm{d}, J=8.4 \mathrm{~Hz}\right.$, inden- $\left.\mathrm{H}^{6}\right), 7.31(1 \mathrm{H}, \mathrm{d}$, $J=8.4 \mathrm{~Hz}$, indolin-2-one- $\left.\mathrm{H}^{6}\right), 7.40\left(1 \mathrm{H}, \mathrm{d}, J=8.4 \mathrm{~Hz}\right.$, indolin-2-one- $\left.\mathrm{H}^{7}\right), 7.54\left(1 \mathrm{H}, \mathrm{s}\right.$, indolin-2-one- $\left.\mathrm{H}^{4}\right) .{ }^{13} \mathrm{C}-\mathrm{NMR}(600 \mathrm{MHz}$, DMSO- $\left.d_{6}\right) \delta(\mathrm{ppm}): 163.51,153.83,148.40,145.82,145.60,141.24,133.78,125.43,125.29,124.83,117.09,115.51$, 114.00, 113.28, 32.66, 32.10, 25.46. ESI-MS $m / z$ : $297.23(\mathrm{M}+1)^{+}$. HRMS (ESI) calculated for $\mathrm{C}_{17} \mathrm{H}_{13} \mathrm{ClN}_{2} \mathrm{O}(\mathrm{MH}+)$, 297.0789; found, 297.0785 .

(Z)-5-chloro-3-[(9-ethyl-9H-carbazol-3-yl)imino]indolin-2-one (8f): Yellow powder, $81.2 \%$ yield, $\mathrm{mp}: 266.6^{\circ} \mathrm{C}-267.5^{\circ} \mathrm{C}$. ${ }^{1} \mathrm{H}-\mathrm{NMR}\left(600 \mathrm{MHz}, \mathrm{DMSO}-d_{6}\right) \delta(\mathrm{ppm}): 1.35\left(3 \mathrm{H}, \mathrm{t}, J=7.2 \mathrm{~Hz},-\mathrm{NH}-\mathrm{C}-\mathrm{CH}_{3}\right), 4.50\left(2 \mathrm{H}, \mathrm{q}, J=7.2 \mathrm{~Hz},-\mathrm{NH}-\mathrm{CH}_{2}-\mathrm{C}\right)$, $6.93\left(1 \mathrm{H}, \mathrm{d}, J=8.4 \mathrm{~Hz}\right.$, indolin-2-one- $\left.\mathrm{H}^{6}\right), 7.19-7.24\left(2 \mathrm{H}, \mathrm{m}\right.$, carbazol- $\left.\mathrm{H}^{7,8}\right), 7.38\left(1 \mathrm{H}, \mathrm{d}, J=8.4 \mathrm{~Hz}\right.$, carbazol- $\left.\mathrm{H}^{9}\right), 7.50(1 \mathrm{H}, \mathrm{d}$, $J=8.4 \mathrm{~Hz}$, carbazol- $\left.\mathrm{H}^{2}\right), 7.65\left(1 \mathrm{H}, \mathrm{d}, J=8.4 \mathrm{~Hz}\right.$, carbazol- $\left.\mathrm{H}^{3}\right), 7.74\left(1 \mathrm{H}, \mathrm{d}, J=8.4 \mathrm{~Hz}\right.$, indolin-2-one- $\left.\mathrm{H}^{7}\right), 7.92(1 \mathrm{H}, \mathrm{s}$, indolin2-one- $\left.\mathrm{H}^{4}\right), 8.16\left(1 \mathrm{H}, \mathrm{d}, J=8.4 \mathrm{~Hz}\right.$, carbazol- $\left.\mathrm{H}^{6}\right), 8.19\left(1 \mathrm{H}\right.$, s, carbazol- $\left.\mathrm{H}^{5}\right) .{ }^{13} \mathrm{C}-\mathrm{NMR}\left(600 \mathrm{MHz}, \mathrm{DMSO}-d_{6}\right) \delta(\mathrm{ppm}): 153.17$, $145.74,141.63,140.38,138.15,133.58,126.50,125.35,124.35,124.09,122.96,122.71,122.40,120.97,119.19,117.62$, $115.09,113.24,110.09,109.71,37.43,13.90$. ESI-MS $m / z: 374.90(\mathrm{M}+1)^{+}$.

(Z)-3-[(1-acetylindolin-5-yl)imino]-5-chloroindolin-2-one (8g): Crimson powder, $75.4 \%$ yield, $\mathrm{mp}: 270.7^{\circ} \mathrm{C}-270.9^{\circ} \mathrm{C}$. ${ }^{1} \mathrm{H}-\mathrm{NMR}\left(600 \mathrm{MHz}, \mathrm{DMSO}-d_{6}\right) \delta(\mathrm{ppm}): 2.18\left(3 \mathrm{H}, \mathrm{s}, \mathrm{N}-\mathrm{CO}-\mathrm{CH}_{3}\right), 3.18\left(2 \mathrm{H}, \mathrm{t}, J=8.4 \mathrm{~Hz}\right.$, acetyindolin- $\left.\mathrm{H}^{3}\right), 4.15(2 \mathrm{H}, \mathrm{t}$, $J=8.4 \mathrm{~Hz}$, acetyindolin- $\left.\mathrm{H}^{2}\right), 6.92\left(1 \mathrm{H}, \mathrm{d}, J=8.4 \mathrm{~Hz}\right.$, acetyindolin- $\left.\mathrm{H}^{7}\right), 6.97\left(1 \mathrm{H}, \mathrm{s}\right.$, acetyindolin- $\left.\mathrm{H}^{4}\right), 7.41(1 \mathrm{H}, \mathrm{d}, J=8.4 \mathrm{~Hz}$, acetyindolin- $\left.\mathrm{H}^{6}\right), 7.45\left(1 \mathrm{H}, \mathrm{d}, J=8.4 \mathrm{~Hz}\right.$, indolin-2-one- $\left.\mathrm{H}^{6}\right), 7.52\left(1 \mathrm{H}, \mathrm{s}\right.$, indolin-2-one- $\left.\mathrm{H}^{4}\right), 8.10(1 \mathrm{H}, \mathrm{d}, J=8.4 \mathrm{~Hz}$, indolin2-one- $\left.\mathrm{H}^{7}\right) .{ }^{13} \mathrm{C}-\mathrm{NMR}\left(600 \mathrm{MHz}, \mathrm{DMSO}-d_{6}\right) \delta(\mathrm{ppm}): 168.78,163.55,153.47,145.83,141.25,133.80,126.56,125.46$, $124.53,122.07,120.76,117.12,116.40,115.72,113.30,48.65,27.62,24.17$. ESI-MS $m / z: 340.45(\mathrm{M}+1)^{+}$.

(Z)-3-[(2-amino-6-morpholinopyridin-3-yl)imino]-5-chloroindolin-2-one (8h): Purple powder, 75.7\% yield, mp: $213.8^{\circ} \mathrm{C}-215.1^{\circ} \mathrm{C} .{ }^{~} \mathrm{H}-\mathrm{NMR}\left(600 \mathrm{MHz}, \mathrm{DMSO}-d_{6}\right) \delta(\mathrm{ppm}): 3.64-3.66\left(8 \mathrm{H}, \mathrm{m}\right.$, morpholino- $\left.\mathrm{CH}_{2} \times 4\right), 6.16(1 \mathrm{H}, \mathrm{d}, J=9.6 \mathrm{~Hz}$, pyrdin- $\left.\mathrm{H}^{5}\right), 6.78\left(1 \mathrm{H}, \mathrm{d}, J=9.6 \mathrm{~Hz}\right.$, pyrdin- $\left.\mathrm{H}^{4}\right), 7.19\left(1 \mathrm{H}, \mathrm{d}, J=8.4 \mathrm{~Hz}\right.$, indolin-2-one- $\left.\mathrm{H}^{6}\right), 7.61(1 \mathrm{H}, \mathrm{d}, J=8.4 \mathrm{~Hz}$, indolin2-one- $\left.\mathrm{H}^{7}\right), 7.93\left(1 \mathrm{H}, \mathrm{s}\right.$, indolin-2-one- $\left.\mathrm{H}^{4}\right), 8.93(2 \mathrm{H}, \mathrm{s},-\mathrm{NH} 2) .{ }^{13} \mathrm{C}-\mathrm{NMR}\left(600 \mathrm{MHz}, \mathrm{DMSO}-d_{6}\right) \delta(\mathrm{ppm}): 159.34,153.47$, $150.51,143.48,139.96,133.71,130.07,126.02,120.86,117.64,111.97,95.97,66.21 \times 2,44.80 \times 2$. ESI-MS $m / z: 358.59$ $(\mathrm{M}+1)^{+}$. 
A
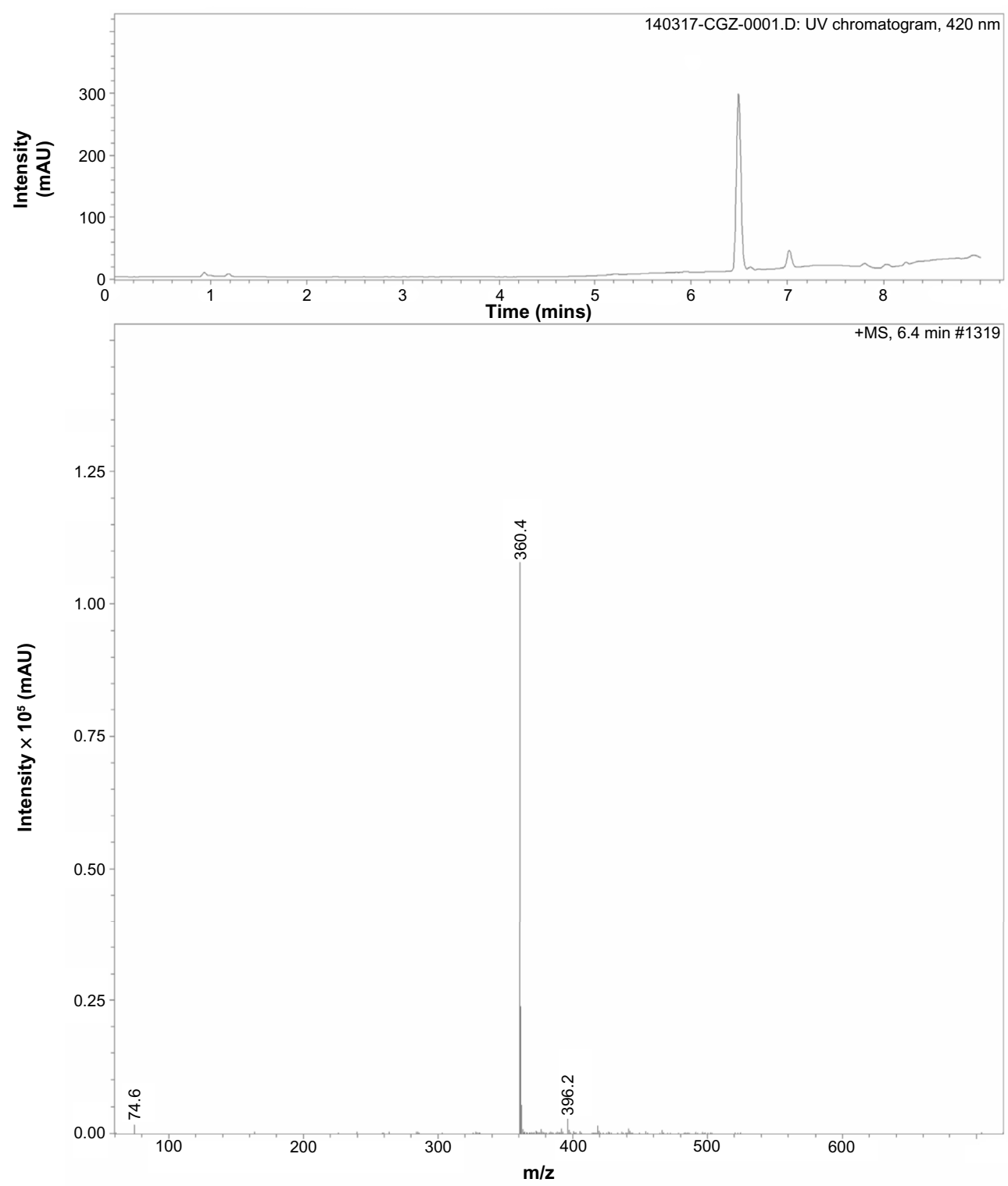

Bruker daltonics data analysis 3.4

Printed: $\quad 3 / 17 / 2014$ 10:14:00 AM

Page 1 of 1 
B
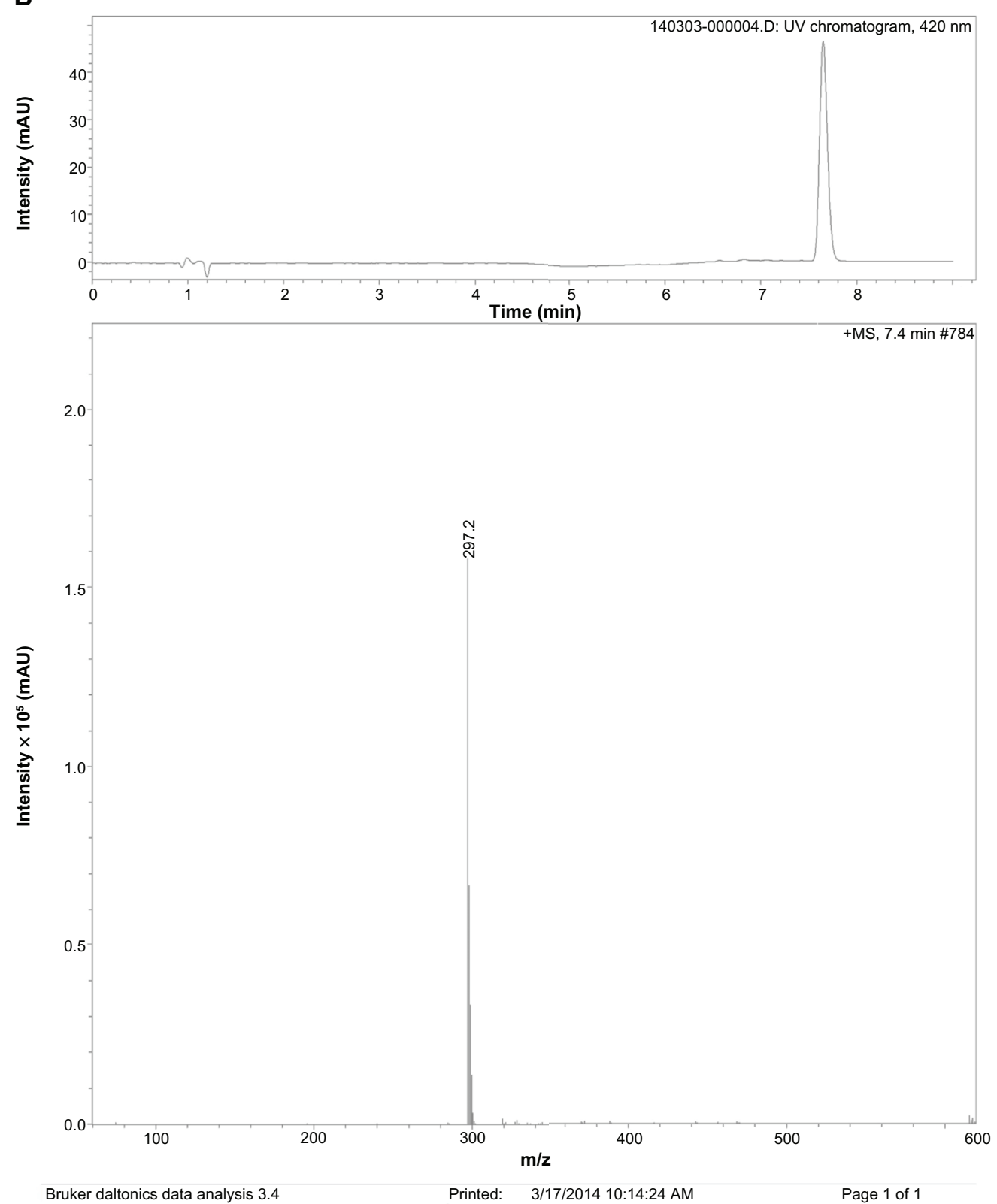

Figure S2 LC-MS of the active compounds.

Notes: (A) LC-MS of compound 7i. (B) LC-MS of compound 8e.

Abbreviations: LC-MS, liquid chromatograph mass spectrometer; MS, mass spectrometer; $\mathrm{m} / \mathrm{z}$, mass charge ratio; UV, ultraviolet rays. 
A

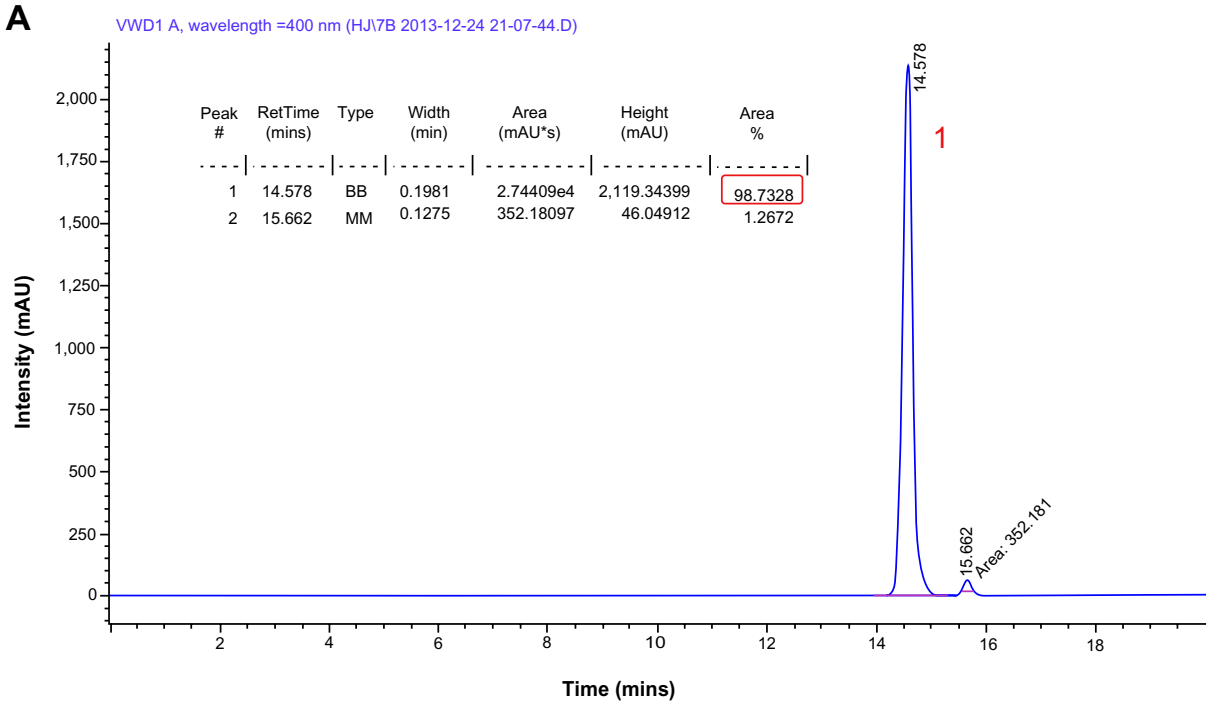

B

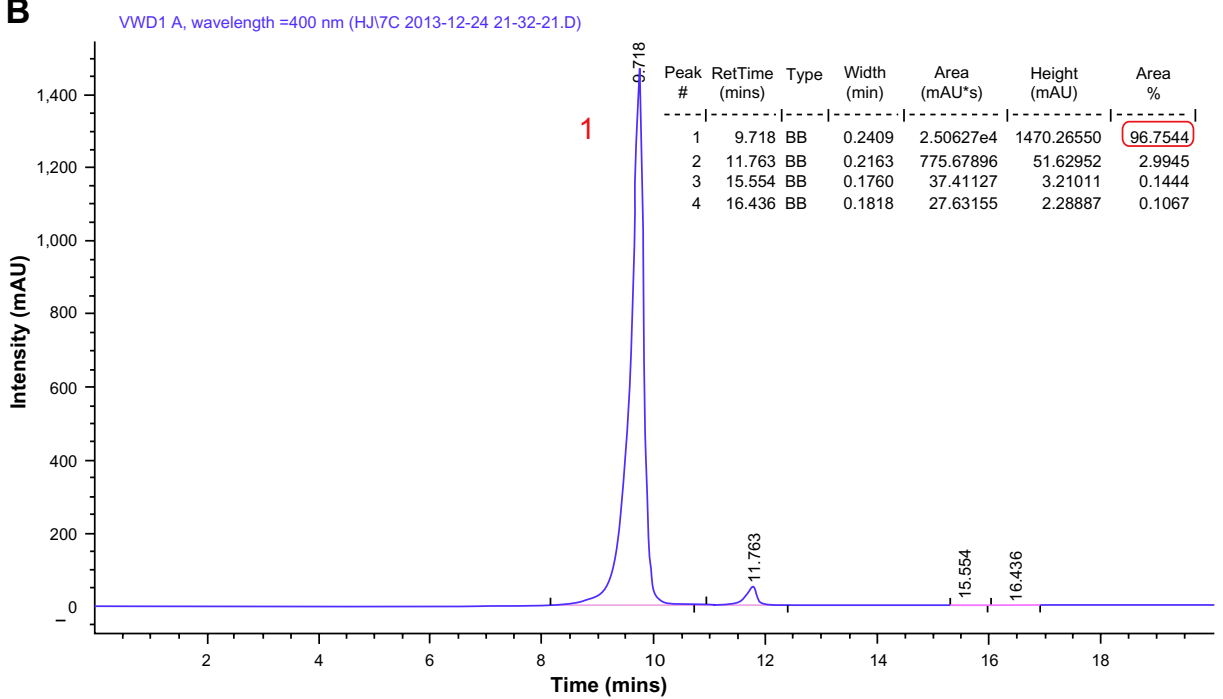

C

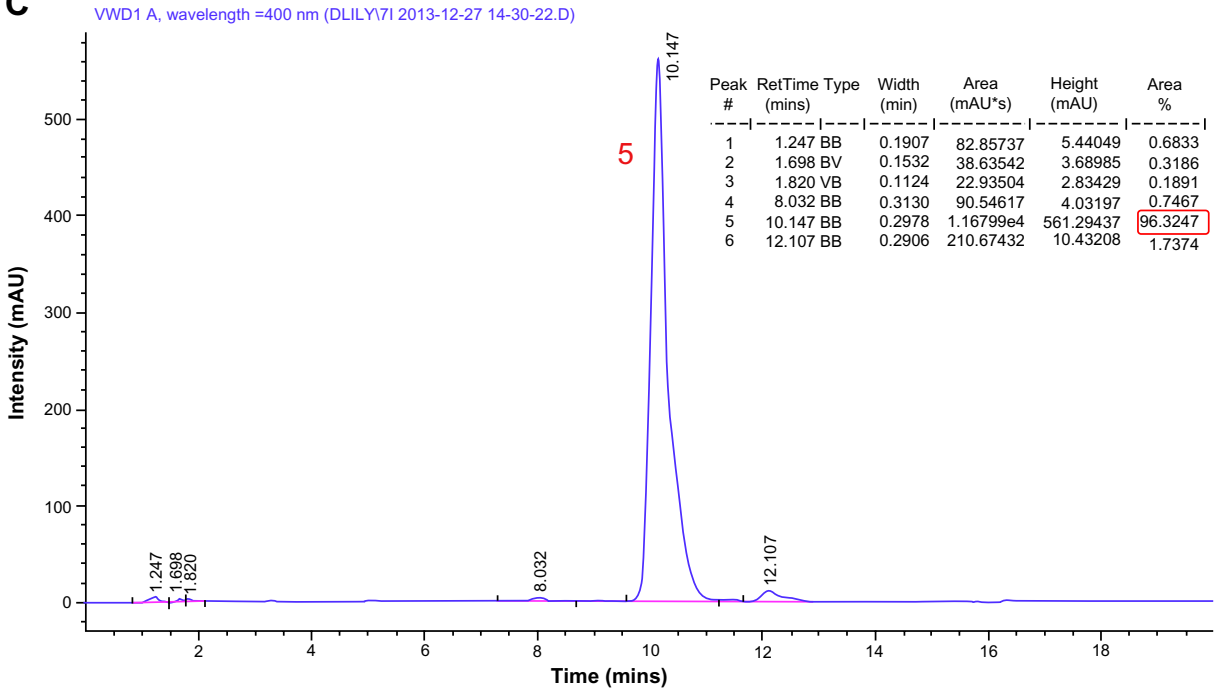



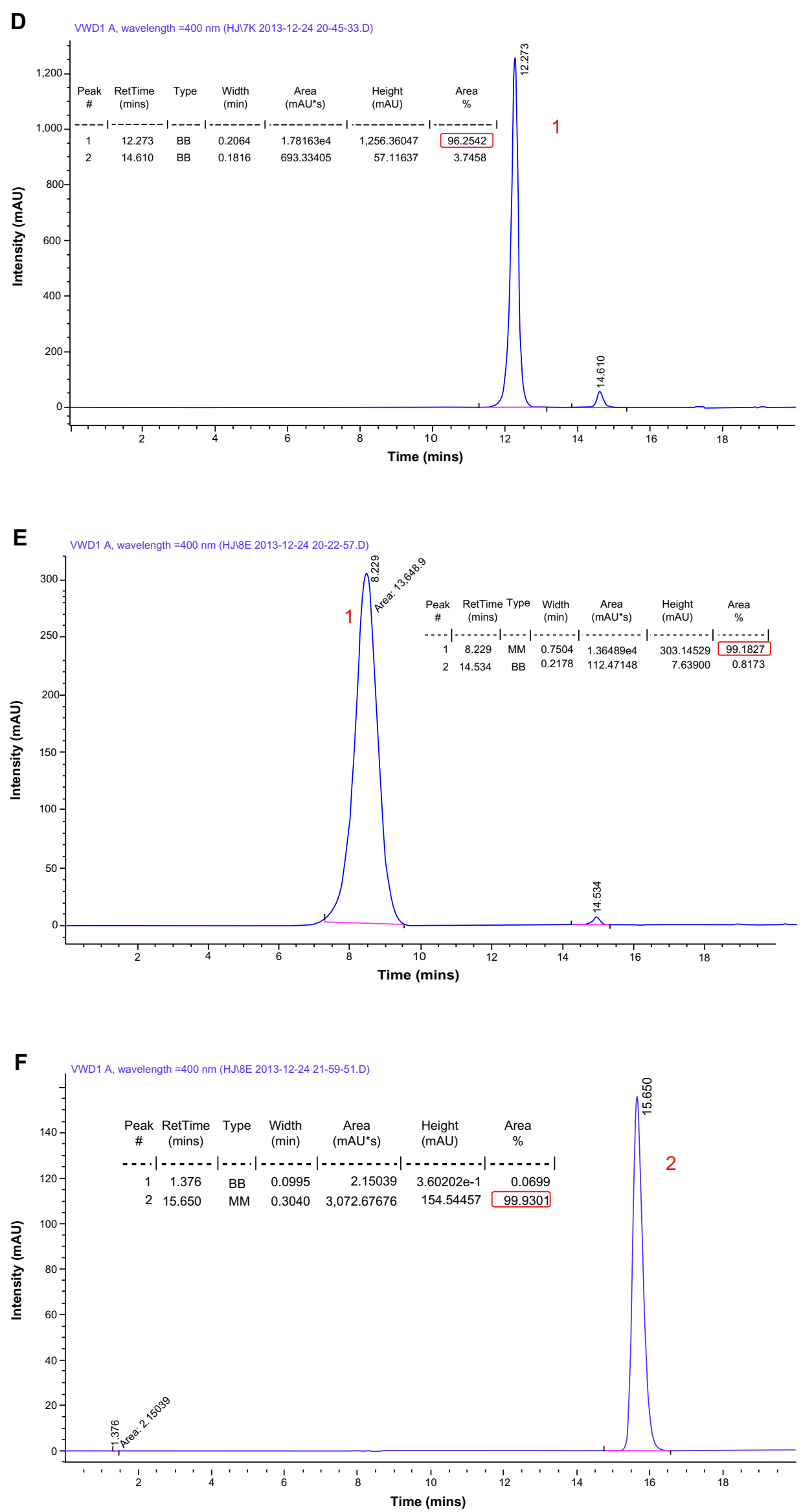

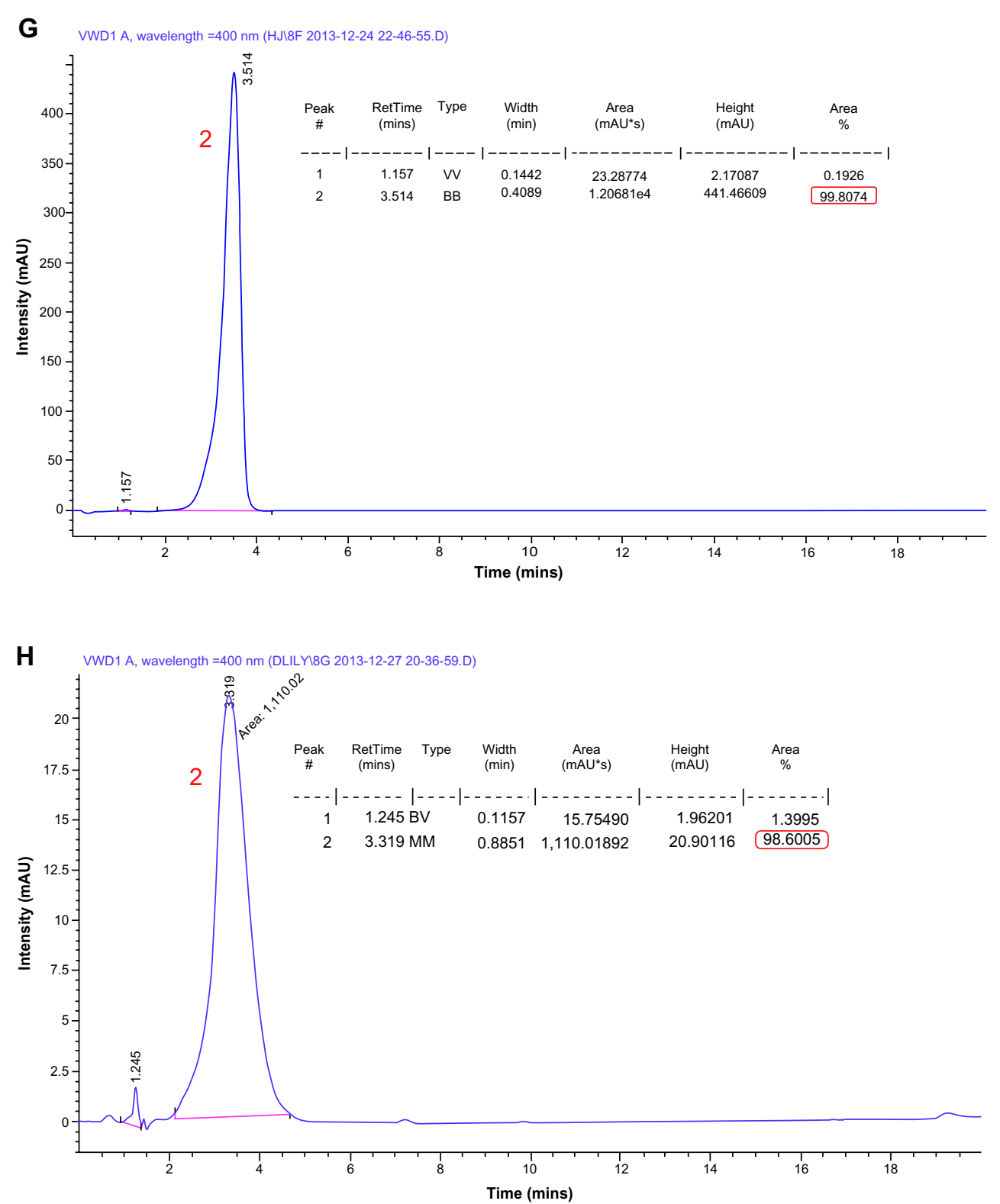

Figure S3 HPLC determination for purity of the representative compounds.

Note: (A) RP-HPLC spectrum of compound 7b: purity $98.73 \%$. (B) RP-HPLC spectrum of compound 7c: purity $96.75 \%$. (C) RP-HPLC spectrum of compound 7i: purity 96.32\%. (D) RP-HPLC spectrum of compound 7k: purity $96.25 \%$. (E) RP-HPLC spectrum of compound 8 d: purity $99.18 \%$. (F) RP-HPLC spectrum of compound 8 e: purity 99.93\%. (G) RP-HPLC spectrum of compound 8f: purity $99.80 \%$. (H) RP-HPLC spectrum of compound 8g: purity $98.60 \%$. The values I, 2 , and 5 beside the peak in each graph denotes the compound is the first, second, or fifth peak shown in the graph. HPLC conditions: column, XDB-CI8 (4.6 mm ID $\times I 50 \mathrm{~mm} \mathrm{~L})$; column temperature, $25^{\circ} \mathrm{C}$; mobile phase, $\mathrm{H}_{2} \mathrm{O} / \mathrm{CH}_{3} \mathrm{OH}=50: 50-10: 90$; flow rate, $1.0 \mathrm{~mL} / \mathrm{min}$; wavelength, UV $400 \mathrm{~nm}$. BB, BV, MM, and VV refer to the type of peak.

Abbreviations: AU, absorbance unit; D, data; HJ, method name; HPLC, high performance liquid chromatography; ID, inside diameter; L, length; RP-HPLC, reversed-phase high performance liquid chromatography; mins, minutes; min, minimum; UV, ultraviolet; VWDIA, variable wavelength UV detector. 
RAW 264.7
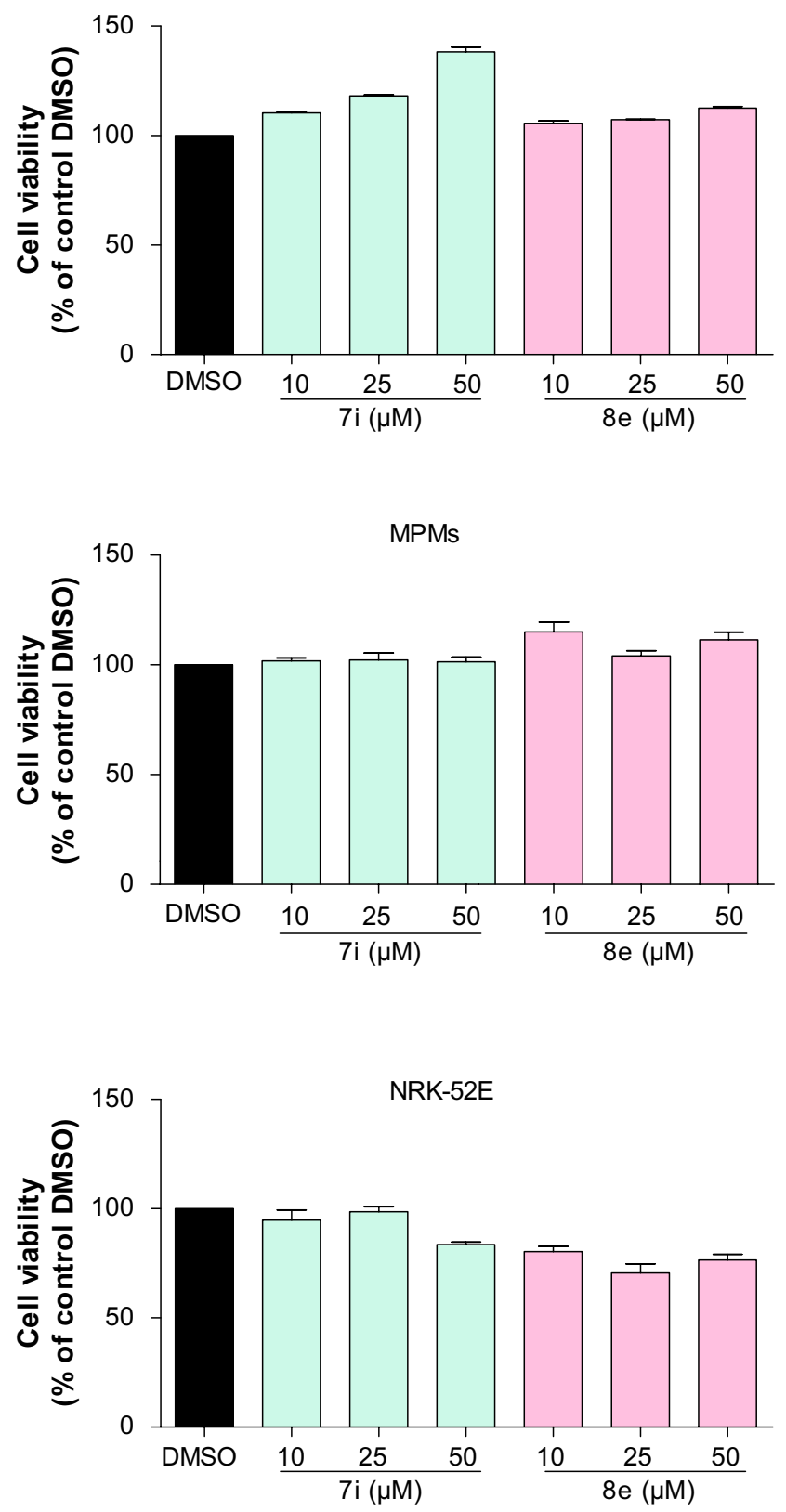

Figure S4 The cytotoxicity of active compounds $7 \mathrm{i}$ and $8 \mathrm{e}$ in RAW264.7 macrophages, MPMs, and NRK-52E cells. Abbreviations: DMSO, dimethyl sulfoxide; MPM, mouse peritoneal macrophage. 


\section{References}

1. Wood ER, Kuyper L, Petrov KG, Hunter RN 3rd, Harris PA, Lackey K. Discovery and in vitro evaluation of potent TrkA kinase inhibitors: oxindole and aza-oxindoles. Bioorg Med Chem Lett. 2004;14(4):953-957.

2. Chen G, Wang Y, He H, Li S, Zhou L, Hao X. Synthesis of isatin derivatives and the biological activity against the Magnaporthe grisea. Acta Botanica Yunnanica. 2007;29(6):717-721.

3. Yang LL, Li GB, Yan HX, et al. Discovery of N6-phenyl-1H-pyrazolo [3, 4-d] pyrimidine-3, 6-diamine derivatives as novel CK1 inhibitors using common-feature pharmacophore model based virtual screening and hit-to-lead optimization. Eur J Med Chem. 2012;56:30-38.

4. Zhang W, Go ML. Functionalized 3-benzylidene-indolin-2-ones: Inducers of NAD (P) H-quinone oxidoreductase 1 (NQO1) with antiproliferative activity. Bioorg Med Chem. 2009;17(5):2077-2090.

5. Furuta T, Hirata Y, Kiuchi K. Oxyindole derivative and nerve cell death inhibitor. Jpn Kokai Tokkyo Koho: JP2011001309 (A) 2011.

6. Vieth M, Cummins DJ. DoMCoSAR: a novel approach for establishing the docking mode that is consistent with the structure-activity relationship. Application to HIV-1 protease inhibitors and VEGF receptor tyrosine kinase inhibitors. J Med Chem. 2000;43(16):3020-3032.

7. Ravindranathan KP, Mandiyan V, Ekkati AR, Bae JH, Schlessinger J, Jorgensen WL. Discovery of novel fibroblast growth factor receptor 1 kinase inhibitors by structure-based virtual screening. J Med Chem. 2010;53(4):1662-1672.

\section{Publish your work in this journal}

Drug Design, Development and Therapy is an international, peerreviewed open-access journal that spans the spectrum of drug design and development through to clinical applications. Clinical outcomes, patient safety, and programs for the development and effective, safe, and sustained use of medicines are a feature of the journal, which

Submit your manuscript here: http://www.dovepress.com/drug-design-development-and-therapy-journal has also been accepted for indexing on PubMed Central. The manuscript management system is completely online and includes a very quick and fair peer-review system, which is all easy to use. Visit http://www.dovepress.com/testimonials.php to read real quotes from published authors. 